NBER WORKING PAPER SERIES

\title{
IS THE DISTANCE TO DEFAULT A GOOD MEASURE IN PREDICTING BANK FAILURES? CASE STUDIES
}

\author{
Kimie Harada \\ Takatoshi Ito \\ Shuhei Takahashi \\ Working Paper 16182 \\ http://www.nber.org/papers/w16182
NATIONAL BUREAU OF ECONOMIC RESEARCH
1050 Massachusetts Avenue
Cambridge, MA 02138
July 2010

We are also grateful for helpful discussions with Ryuzo Miyao, Kiyotaka Nakashima and Toshiyuki Souma and for insigutful comments from participants in Japanese Economic Association in 2008. The views expressed herein are those of the authors and do not necessarily reflect the views of the National Bureau of Economic Research.

NBER working papers are circulated for discussion and comment purposes. They have not been peerreviewed or been subject to the review by the NBER Board of Directors that accompanies official NBER publications.

(C) 2010 by Kimie Harada, Takatoshi Ito, and Shuhei Takahashi. All rights reserved. Short sections of text, not to exceed two paragraphs, may be quoted without explicit permission provided that full credit, including $\odot$ notice, is given to the source. 
Is the Distance to Default a Good Measure in Predicting Bank Failures? Case Studies

Kimie Harada, Takatoshi Ito, and Shuhei Takahashi

NBER Working Paper No. 16182

July 2010

JEL No. G19,G21

\begin{abstract}
$\underline{\text { ABSTRACT }}$
This paper examines the movements of the Distance to Default (DD), a market-based measure of corporateldefault risk, of eight failed Japanese banks in order to evaluate the predictive power of the DD measurelfor bank failures. The DD became smaller in anticipation of failure in many cases. The DD spread,Ldefined as the DD of a failed bank minus the DD of sound banks, was also a useful indicator for deterioration bof a failed bank's health. For some banks, neither the DD nor the DD spread predicted

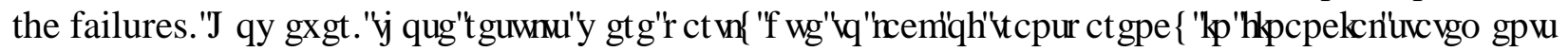
and disclosedlinformation.
\end{abstract}

Kimie Harada

Graduate School of International Accounting Chuo University

Ichigaya-Tamachi 1-18

Shinjuku-ku, Tokyo 162-8478

Japan

kimieh@tamacc.chuo-u.ac.jp

Takatoshi Ito

Graduate School of Economics

University of Tokyo

7-3-1 Hongo, Bunkyo-ku, Tokyo 113-0033

JDSDQ

and NBER

ITOINTOKYO@aol.com
Shuhei Takahashi

Department of Economics

The Ohio State University

410 Arps Hall

1945 N High Street

Columbus, $\mathrm{OH}, 43210$

takahashi.35@osu.edu 


\section{Introduction}

Until the late 1980s, failing banks were rescued by mergers arranged by Ministry of Finance (MOF) with healthier banks without any financial subsidies but regulatory favors. After the bursting of the bubble economy in the beginning of the 1990s, the profitability of Japanese banks steadily worsened, and many smaller Japanese banks had been failing. The Deposit Insurance Corporation (DIC) was used to assist mergers. Toho Sogo Bank, a regional bank, failed (i.e., became insolvent) in 1992 was absorbed by Iyo Bank with financial subsidies from DIC to Iyo Bank. This became the case of DIC assisted merger, and became a typical formula for dealing with a failing bank. ${ }^{1}$ Then, a size of failing bank gradually increased. In 1995, Hyogo Bank became the first stock exchange-listed bank to fail. Market participants reacted to the failure, but judged the failure as an isolated event as it did not bring impacts to the entire banking industry (Ito and Harada (2005)). There was only few bank failure in 1996.

A false sense of calm was broken abruptly in November 1997, when two large financial institutions and two smaller ones failed triggering a full-fledged banking crisis. Credit risk of Japanese banks became one of the major concerns in the global financial market (The list of failed banks is in Table 1). The so-called Japan premium became substantially higher in November 1997, and continued to be high. In reaction to failure in banking policy, the supervision power was taken away from MOF and a new supervision agency, Financial Supervisory Agency (FSA) was established in 1998. This was a major change in separating supervisory function from the fiscal authority and nurture specialized human capital for supervision. ${ }^{2}$

Despite capital injection of March 1998, two additional large banks failed in the latter half of 1998. DIC faced revenue shortfalls, and additional funds were injected.

After the banking crisis of November 1997, large banks and some regional banks decided to merge for survival as their capital bases were damaged by nonperforming loans (NPLs).

\section{Table 1 is about here}

1 This formula is described as hougacho (subscription list) in Hoshi and Patrick (2000). It implies that the Ministry of Finance solicits healthy banks for funds to prop up a weak bank.

2 The agency was later renamed as Financial Services Agency (FSA) 
There are several general measures of bank vulnerability and more specific measure for the probability of bank failure. A first candidate would be credit ratings. However, how credit rating is done is a black box to outsiders, and there have been persistent criticism that downgrades often lag behinds other obvious signs rather than foretelling what would come. This was the case for Japanese banks in the mid-1990s. Crucial downgrades came only weeks before banks' failures. Capital adequacy ratio (CAR), adopted by Basel Committee on Bank Supervision, provides how much capital is prepared for risk-weighted assets. However, it was not particularly a good measure predicting bank financial health, as there are many ways for "window dressing." In particular, Japanese banks in the mid-1990s were struggling to maintain a high CAR using various provisions to boost capital and to compress loan loss reserves based on optimistic assumption. ${ }^{3}$ For example, the Long-Term Credit Bank of Japan had more than 11\% CAR in March 1998, but became insolvent in October 1998.

Hanajiri (1999) and Ito and Harada (2005) showed that Japanese banks had to pay the so-called "Japan premium", in the interbank borrowing from western banks. They showed that the Japan premium reflected fragility of Japanese banks from mid-1990s to spring of 1999, when capital injection made Japanese banks good buffer. Related indicators showing market participants' evaluations of bank health are premiums of the Credit Default Swaps (CDS). The CDS is a rather new indicator and prevails in analyzing Japanese banks after the Japan premium disappeared. Ito and Harada (2004, 2006), Ueno and Baba (2006) and Okada (2007) used the CDS in order to see fragility of Japanese banks. ${ }^{4}$ Premiums in the interbank money market and the CDS are observed in the markets. However, market participants of CDS for Japanese banks are said to be limited to particular financial institutions and the market is shallow.

The Distance to Default (DD) is a market-based measure of corporate default risk. It is based on evaluation of assets in the stock markets, where participants are heterogeneous and diversified, and book values of short-term debts. It measures both solvency risk and liquidity risk. This is an alternative measure for financial

3 See Ito and Sasaki (2002) on how Japanese banks issued subordinated debts to boost tier 2 capital in response to shrinking tier 2 component, unrealized capital gains of their equity holdings.

4 The CDS is not traded for banks and institutions that are already in financially bad shape. Government-affiliated companies and relatively small companies are not traded in the CDS market, either. With the DD, we can evaluate banks which are government-affiliated and which are not traded in the CDS market. 
vulnerability of a corporation. As stock prices are available almost every business days, the measure is continuously available. Harada and Ito (2008) applied the measure to banks to analyze merged banks to answer a question whether mergers made merged banks financially more robust than the pre-merger individual banks. This paper applied the DD to failed Japanese banks in order to see whether the measure was suitable for assessing default risks of banks.

The DD in this paper is based on a structural approach of the Merton (1974)'s model and Black and Scholes (1973)'s option pricing model. This paper examines whether the DD is useful in predicting failure of a bank in the near future.

The rest of the paper is structured as follows. Section 2 reviews the history of bank failures and the rescue system. Section 3 describes the DD methodology and reviews the DD application to banks. We create the DD in section 4 and compare the DDs of failed banks and the benchmark bank. Section 5 concludes the paper.

\section{History of Bank Failures}

\subsection{Bank Failures in Japan}

The Japanese bank supervision could be characterized as a no-failure policy (or the convoy system) until the end of the 1980s. Any failing bank could be arranged to be merged with a stronger bank that were eager to expand. Although DIC was established in 1971, no merger case emerged for two decades, and collected insurance premia were accumulated as a fund in DIC. In 1991, the first case of DIC assisted take-over merger of a weak bank by a healthier bank took place. A small bank, Toho Sogo Bank (213 billion yen in assets) was determined to have failed and Iyo Bank was given subsidies worth 2 billion yen to take over assets and liabilities of Toho Sogo Bank. Between 1992 and July 1994, there were 4 cases of similar small bank failures. In 1995, the Tokyo Kyodo Bank was established by DIC and Tokyo metropolitan government to take over two relatively large credit cooperatives in Tokyo, Tokyo Kyowa and Anzen, reflecting the fact that it became difficult to find a white knight quickly. In July, another large credit cooperative, Cosmo Credit Coop, failed and taken over by Tokyo Kyodo Bank (See Table 2 for detailed history of failures and DIC in the 1990s).

In August 1995, Hyogo Bank (assets, 3,400 billion yen) and Kizu Credit Coop (assets, 1,200 billion yen) failed and DIC assistance, amounting to 100 billion yen, for the two institutions almost exhausted the DIC fund. The failure of Hyogo Bank was significant because it was the first listed bank to fail in the Japanese postwar history. 
(See Ito (2000) and Cargill, Hutchison and Ito (1997, ch. 6) for a more detailed explanation).

\section{Table 2 is about here}

Although there were no bank failures in 1996, that was calm before the storm. In November 1997, four financial institutions failed, of which two of them were quite large. Hokkaido Takushoku Bank was one of the Big 20 large banks, which the Ministry of Finance had promised to protect earlier, but it failed for possible insolvency. The business was divided and sold to other financial institutions after being declared failure, with very distressed assets were purchased by the public bad bank, Resolution and Collection Bank that was enhanced Tokyo Kyodo Bank. Yamaichi Securities, one of the Big 4 securities firm at the time, also failed and liquidated in the same month.

Following the November 1997 shock, western banks started to charge the "Japan premium" which reflected the distrust of Japanese banks and bank supervision by foreign banks. Since DIC fund had been exhausted, the new funding was proposed and established. Capital injection for remaining banks from the newly obtained fund was hastily arranged in March 1998. (See Cargill, Hutchison and Ito (2000, ch. 2) for detailed for the financial distress during this period).

As the size of capital injection of March 1998 was too small to stabilize the financial system, instability and uncertainty persisted in 1998. In the summer of 1998, special legislation was prepared, which authorized the regulator to take over financial institutions if they are systemically important and near insolvent. The new financial regulator, Financial Supervisory Authority, was established in June 1998.

Two laws were passed in October 1998; one is the Law Concerning Emergency Measure for the Reconstruction of the Functions of the Financial System (The Financial Reconstruction Act), which allows the authorities to deal with a failed bank without finding a healthy receiving bank; the other is the Financial Function Early Restoration Law, which permitted the authorities to provide funds for bank resolution. Soon after these laws were enacted, two major banks were nationalized. ${ }^{5}$

Using the new authority and legislation, Long-Term Credit Bank (LTCB) of Japan and Nippon Credit Bank (NCB) were taken over by the government in October

5 Details of the two acts and the impacts of the acts on the stock market are examined in Spiegel and Yamori (2003). 
and December, respectively, 1998. These were in the category of long-term credit banks, providing long-term development loans to large corporations. Business model and strict entry limit to the category made those banks very profitable in the 1960s-80s. However, distressed assets mainly from construction and real estate companies overwhelmed their capital. The failure of LTCM was long rumored in the market, and the stock prices had steadily declined in the spring and summer, until its failure on October 23, 1998. The failure of NCB was rather surprise as the stock prices were stable until the day before the announcement of failure and takeover by the regulator. The second capital injection in 1999 amounted to 7.6 trillion yen, four times as much as the first injection.

Between 1999 and 2002, the Japanese banking system appeared to have regained stability, as no major bank failed. Capital injection and the power to nationalize a bank, if near insolvency, seemed to have worked. However, the calm was deceptive, as tax-deferred assets (TDA) had become a relatively large component of tier 1 capital, although the TDA had no tangible value unless future profits materialize. If loss continues, TDA could suddenly disappear. As this accounting problem became well-known to the public, Japanese banks suddenly looked very vulnerable in 2002. As FSA Minister changed from Mr. Yanagisawa to Mr. Takenaka, regulatory policy of FSA became very tough. Mr. Takenaka demanded on banks to raise more equities to fatten regular tier 1 capital instead of TDA, with a threat to cancel TDA qualifying for tier 1 capital. The plan was commonly called as the Takenaka plan. Recognition of a problem with TDA became wide-spread in 2003, and accounting firms started to deny full attribution of TDA to tier 1 capital. Two more banks-Resona and Ashikaga—failed and were de facto nationalized in 2003.

\subsection{Related Literature}

What had happened in the Japanese banking sector during the 1990s and 2000s was described in many papers and books. Hoshi and Kashyap (2001) painted a bleak picture of the problematic relationship between Japanese banks and corporations from the viewpoint of corporate governance. Chapters in Cargill, Hutchison, and Ito (1997, 2000) give detailed descriptions of the earlier stage of Japanese bank failures. Hoshi and Ito (2004) review the evolution of the regulatory system in Japan from 1998 to 2004. Sakuragawa and Watanabe (2007) evaluate the Takenaka plan of 2002, which has been credited for revival of the Japanese banking sector after 2003.

Brewer et al (2003) examined the stock market's response to failures of banks 
and securities firms by using the event study approach. They find that share prices of surviving banks responded unfavorably to the failures and that financially weaker survivors were more adversely affected. Similar findings are suggested in Ito and Harada (2006). Spiegel and Yamori (2004) analyzed share values of banks in order to find evidence of the "too big to fail". In terms of the Japan premium, Peek and Rosengren (2001) investigated the effect of bank failures on the premium.

The DD is known as a market-based measure for assessing the default or credit risk of non-financial corporations. The indicator has recently been used to monitor risks of financial institutions by international organizations and financial authorities. For example, European Central Bank (2005) treats the DD as an important forward-looking indicator that can provide early signs of financial fragility. In the case of cross-border contagion, the DD can be used as a comprehensive measure of default risk (Gropp, Lo-Duca and Vesala (2006), De Nicolo and Tieman (2006)). Chan-Lau and Sy (2007) introduce the concept of distance to capital, which accounts for pre-default regulatory actions, such as the prompt-corrective-action framework. The distance to insolvency is introduced and applied by Danmarks National Bank (2004). The DD is the base from which these new measures were derived and it is used to analyze various risks, such as contagion risk (Duggar and Mitra (2007) and Chan-Lau, Mitra and Ong (2007)). Chan-Lau and Sy (2007) use a case study approach for two Japanese banks (Resona and Ashikaga Banks) with two different measures, the distance to default and the distance to capital. Chan-Lau and Sy (2007) is the closest to our paper as they examine failed Japanese banks with the DD. However, their paper focuses on the calculation of the distance to capital. The case studies are complementary. This paper thoroughly examines most failed Japanese banks and comprehensively evaluates the DD. We use the DD rather than related measures as the $\mathrm{DD}$ is a basic and widely used measure of credit risk assessment in literature.

\subsection{Cases of Three Large Bank Failures}

By March 2002, 180 deposit-taking institutions had failed in Japan (the DIC annual reports 2005 and 2006). Among, those, we examine eight bank failures, of which Hokkaido Takushoku Bank, Long-term Credit Bank of Japan (LTCB), and Nippon Credit Bank (NCB), were among the group of largest banks in terms of the asset sizes. The financial assistance given to them in total exceeded 40 trillion yen. Five smaller banks--regional banks and second-tier regional banks —-will also be examined.

Resona bank, Japan's fifth-largest bank, was virtually nationalized in May 
$2003,{ }^{6}$ as the bank's capital adequacy ratio fell below the $4 \%$ level, However, the Bank is not included in our analysis. Resona bank was formed by the merger of Daiwa Bank, Asahi Bank and three smaller banks in 2002 and the time span between its creation in 2002 and its failure in 2003 is too short to calculate DD.

\section{Hokkaido Takushoku Bank (HTB)}

HTB was established in 1899 as a "Special Bank" to promote economic development of Hokkaido Prefecture by providing long-term, low-interest loans. ${ }^{7}$ In 1939, HTB increased its scale of operations after being allowed to handle bank accounts by an amendment to the law. HTB became an ordinary bank in 1950 and a city bank in 1960 . HTB, however, opened branches in urban areas, such as Tokyo and Osaka, around 1985 and started to provide real estate loans.

At the time of the asset price bubble in the second half of the 1980s, almost all banks increased their real estate-related loans. Also, it was widely believed that the loan-to-value ratio increased in almost all banks as the real estate priced skyrocketed. HTB was no exception in increasing real estate loans, but HTB had disadvantage compared to other city banks (top 20 banks). As the bank was headquartered in Hokkaido, their expertise in real estate loans in Tokyo and Osaka area was much less than other banks. HTB was a newcomer in Tokyo and Osaka and its expansion in loans meant that they lent to inferior borrowers, or to compromise to be a low-ranked lien holder. The recovery ratio for HTB was believed to be less than other banks, once the bubble burst in the 1990s. HTB was long considered to be the financially weakest as well as smallest among the city banks.

It turned out that NPLs of HTB reached more than $13 \%$ of its total lending in March 1997. The ratio was the highest among city banks. The Ministry of Finance, which earlier declared "no bank among the top 20 banks would fail," proposed a plan to merge HTB with Hokkaido Bank, a regional bank and the second largest bank in Hokkaido. The plan of merger was announced on April 1, 1997, to be completed within

${ }^{6}$ In early 2003, Resona Holdings (the parent company of the bank)' capital adequacy ratio fell critically low and the value of deferred tax assets was denied by the accounting firm. Without being able to count the deferred tax assets as the tier one capital, the bank was near insolvent. On May 17, 2003, the government decided to inject 1.96 trillion yen of public funds into Resona Group through Resona Bank, not the holding company. This injection was not nationalization although the government emerged as the largest shareholder, holding $68.25 \%$ of voting rights of the holding company.

7 The bank was established under “The Agriculture and Industry Banking Law” of 1896. 
a year.

Then the merger plan was virtually called off on September 12, 1997, although the announcement said a half-year postponement to complete the merger, due to a disagreement over the amount of NPLs. On the same day, HTB also announced a restructuring program including the disposal of NPLs. After these announcements, the stock price declined and deposit levels started to drop. Deposits decreased to 5.9 trillion yen in September 1997 although the bank had 8.7 trillion yen deposits in 1994 . The stock price fell to 100 yen in mid-September, which was then considered to be a level for a bankruptcy warning. The stock price continued a decline and became 65 yen the day before the announcement of failure.

Sanyo Securities, a midsized security company, failed on November 4, 1997 and it defaulted on the call loan from a small size trust company, Central Gunma Trust Fund. This was the first ever default in the call market. The call market seized up, and HTB faced great difficulty in borrowing in the call market. Under such circumstances, HTB had no choice but asked for help from the regulators. On November 17, HTB failed. It was the first failure of a city bank in postwar Japan. It was de facto nationalized and to be liquidated.

November 1997 began with the failure of Sanyo Securities on November 3, followed by the failure of HTB on November 17, the failure of Yamaichi Securities, one of the "big four" securities companies, on November 24, and the Tokuyo City Bank on November 26. November 1997 has been remembered as the darkest month of in the Japanese financial trouble in the 1990s.

One year later, the operations in Hokkaido of HTB were transferred to the North Pacific Bank, while operations outside Hokkaido were transferred to Chuo Trust and Banking Co. Its bad loans were sold to the DIC. Monetary grants provided by the DIC were 1.795 trillion yen and asset purchase by the DIC was 1.617 trillion yen.

Since the stock prices were declining, difficulties of HTB were well-known. So its failure was not total surprise to any investor, given its balance sheet and non-performing loans. However, the failure of the government to rescue it was a surprise, since the Minister of Finance had said, "no city bank would fail". Hence, it would be interesting to check with the data how the market was evaluating the DD before its ultimate failure.

\section{Long-term Credit Bank of Japan (LTCB)}

LTCB was founded in 1952 to provide long-term financing to large manufacturing 
industries in Japan. Along with other two long-term credit banks-Industrial Bank of Japan and Nippon Credit Bank-LTCB played an important role for postwar economic development. LTCB had been listed on the Tokyo Stock Exchange (TSE) since 1970.

In 1989, the bank was the ninth-largest bank in the world in terms of assets, and the largest dealer of yen-denominated foreign debt (Samurai Bonds). However, with the burst of the asset price bubble, LTCB faced a great deal of NPLs, mainly from loans to companies in the real estate, construction and housing finance businesses.

In spite of capital injection by the government in March 1998 to all major banks, the stock price of LTCB started to drop in the spring of 1998, and the pace had accelerated in the summer. The authorities tried to rescue it by another injection of public capital along with forcing a merger with Sumitomo Trust and Banking Co., one of the few stable banks at that time. The plan did not succeed because Sumitomo Trust and Banking was skeptical about the true size of LTCB's NPLs. The government was worried about the large size of LTCB if it were to fail, so that the Diet attempted to introduce a new law to nationalize a bank.

The Financial Reconstruction Act and the Financial Function Early Restoration Act passed the Diet in October 1998. The Financial Recovery Act established the framework for dealing with failing banks and its first case was the nationalization of LTCB. Later, the same law was used to nationalize the Nippon Credit Bank and five second-tier regional banks. The Rapid Revitalization Act allowed for the injection of public funds for solvent Japanese banks that became short of capital.

LTCB voluntarily applied for nationalization shortly after the passage of these laws and its NPLs at the time were removed under the application of the laws. Losses were covered by scrapping the existing shareholders' value and new capital injected by the DIC. LTCB's stock price was 210 yen at the beginning of 1998 which dropped to below 60 yen by the end of June. It was 1 yen by the time the bank was nationalized. Nationalization of LTCB was anticipated by the market participant in the protracted debate in the Diet.

In the spring of 2000, the government decided to sell LTCB back to the market. Ripplewood had competed against Chuo Mitsui Trust and Banking Co., for the acquisition of LTCB and won the bid. Ripplewood Holdings, a US investment fund, bought the LTCB for 1 billion yen (9.5 million dollar) in March 2000, with "Defect Warranty Provision," a put option to return assets to the government even after the 
purchase. ${ }^{8}$ This provision was used extensively by Ripplewood to get rid of the bad assets. The new bank then began operations as a private commercial bank on March 1, 2000 and was renamed as Shinsei Bank on June 5, 2000. Shinsei Bank had a successful initial public offering in 2004 after being relieved of bad assets carried over from LTCB balance sheet.

Anecdotal evidence in that the market had long anticipated the failure of LTCB should be also confirmed by the DD measure of LTCB.

\section{Nippon Credit Bank (NCB)}

NCB was another long-term credit bank in Japan. Japan Real Estate Bank (Nihon Fudosan Ginko), a predecessor to NCB, was established in 1957 by the government from balance sheets of Chosun Bank and Taiwan Bank in order to provide long-term finance related to real estate businesses. With real estate financing being one of main businesses, the bank had financial difficulty during the economic slump after the first oil crisis in 1973-74 and was renamed NCB in 1977 with its shift in main business line from real estate businesses to more diversified lending. Hence, when the larger bubble burst in the 1990s, it was no surprise that NCB was again in trouble.

NCB had their first deficit in March 1996. A former administrator of the National Tax Agency and a former senior general manager of the Bank of Japan were installed as bank executives in 1996. The capital adequacy ratio dipped below the critical 4\% level in March 1997. Immediately, the MOF then took a central role and prepared restructuring for NCB. The restructuring plan had two major parts; selling all branches of $\mathrm{NCB}$ and raising about 300 billion yen in subscription to new shares in fundraising campaign. The fund-raising was implemented in the spirit of the convoy system, that is, other banks were forced to assist the weakest financially in the name of protecting financial systemic stability.

NCB had a capital deficit of 94 billion yen at the end of March 1998. Although NCB survived by receiving a capital injection by the Bank of Japan in 1997 and public funds of 60 billion yen from the DIC in March 1998, its asset values further deteriorated in 1998.

NCB abandoned a previously announced merger with Chuo Trust and

8 Defect Warranty Provision (kashi tanpo joko) was protection that the seller (government) gave to the buyer (Ripplewood for LTCB). The buyer can demand that the government buy back any loans whose prices declined by more than $20 \%$ within three years of purchase. This provision was also given to the buyer of Nippon Credit Bank. 
Banking on December 9, 1998. Shortly after, it was reported that NCB was insolvent. On December 12, 1998, the government urged NCB to apply for nationalization and the bank had to comply the following day, under the Financial Reconstruction Law. (Asset purchase by the DIC was 299 billion yen in 1999 and 82 billion yen in 2000. In addition, monetary grant of 3,243 billion yen in 2000 was made before its sales to potential investors). The involuntary nationalization of NCB was sudden and took investors by surprise. The stock price of NCB had been reasonably high and stable prior to nationalization. However, the stable stock price did not mean that the bank was secure. This was partly due to one of the guidelines of TSE on the allocation of new shares to third parties. NCB issued new stocks in 1997. The TSE guideline prohibits selling privately allocated stocks during the first two years after their issuance. ${ }^{9}$

The bank was sold to a Japanese Fund led by SOFTBANK Corp., ORIX Corporation, Tokio Marine and Fire Insurance Co. and other financial institutions. The new bank began operations on September 1, 2000 and was renamed as Aozora Bank in January 2001.

The case of NCB is interesting. Although the bank's weak and constantly deteriorating portfolio was well-known in the market, the bank was regarded to be too connected to be resolved. The fact that the Ministry of Finance forced a convoy-system plan in March 1997 gave an impression that something will be orchestrated in 1998. But this time was different under the newly established law that gave an option to nationalize it. How it is viewed in the DD measure is an interesting point.

\subsection{Smaller Regional Bank Failures}

\section{Hyogo Bank}

Hyogo Sogo Bank was formed through the merger of three local banks in Hyogo prefecture in 1944 and it changed its name to the Hyogo Bank in 1989. It operated mainly in Hyogo prefecture.

Hyogo Bank failed in August 1995. The failure of Hyogo Bank was the first listed bank failure since World War II. The bank had already been in trouble in the first half of the 1990s due to declining land price and damages from a huge earthquake in Hyogo prefecture. The Ministry of Finance identified Hyogo bank as insolvent through its inspection, on August 31, 1995. The stockholders of Hyogo bank lost their equity

9 The guidelines are listed under paragraph 422 of the rules for listing and paragraph 428 of the rules of practice. 
value. The successor bank was Midori Bank.

\section{Taiheiyo Bank}

Taiheiyo Bank was established in 1911 as a mutual bank. The bank changed its name from Daiichi Sogo Bank in October 1989 when it changed from a "Sogo", mutual bank to an ordinary bank (second-tier regional bank).

Taiheiyo bank failed on April 1 1996. Then, the DIC contributed 117 billion yen to the resolution of the bank. Four city banks of Sakura, Fuji, Tokai and Sanwa took hair cut in their claims to Taiheiyo Bank, but set up a receiver bank, Wakashio Bank. Remaining assets of Taiheiyo Bank was transferred to Wakashio Bank. Later, Wakashio Bank became a subsidiary of Sumitomo Mitsui Financial Group. Through the merger of its main banking subsidiary, Sumitomo Mitsui Banking Co., Wakashio Bank was renamed Sumitomo Mitsui Banking Co. .

\section{Hanwa Bank}

Hanwa Bank was the second largest regional bank in Wakayama Prefecture. It became apparent that the bank's financial condition deteriorated and the amount of debt exceeded the capital through an inspection by the Ministry of Finance. On November 11, 1996, the MOF ordered to suspend business operations except for the repayment of deposits, pursuant to Article 26 of the Banking Law. Unlike previous failures, the Ministry of Finance did not attempt to find a rescue bank, but liquidated the bank, by shifting balance sheets to the DIC. At that time, the Bank of Japan and the MOF

repeatedly indicated that prompt measures to deal with insolvent financial institutions would be taken. The DIC set up Kii Yokin Kanri Bank as the bank for deposit payback so that depositors were protected. The bank was liquidated in March 2002 after almost all deposits were repaid.

\section{Tokyo Sowa Bank}

The FSA revealed that Tokyo Sowa Bank's negative net worth was about 119 billion yen at interim period of 1998. After the revelation, the stock price took a sharp decline and about 200 billion yen in deposits were withdrawn.

The bank received an order from the Financial Reconstruction Commission to be placed under the management of the government by the Financial Reconstruction 
law, i.e., bank failure, in June 1, 1999. ${ }^{10}$ Later, Lone Star, a US private equity firm, bought failed Tokyo Sowa Bank in June 2001 for 40 billion yen. Tokyo Sowa Bank was listed and renamed as Tokyo Star Bank, in late 2005.

\section{Ashikaga Bank}

Ashikaga Bank was the 10th largest regional bank and major bank of the Ashigin Financial Group. Ashikaga Bank received a total of 135 billion yen in capital injection in 1998 and 1999. Public money was supposed to be injected into viable banks, but Ashikaga Bank could not pay dividends after the injections. Ashikaga Bank issued 60 million preferred shares, which was equivalent to 30 billion yen in 1999 and again another 30 billion yen was raised in ordinary stocks in 2002. In terms of deposits, the bank experienced a near bank run in 1997. Total deposits were about 5,374 billion yen at the end of September 1997, of which 300 billion yen was withdrawn within a year.

The FSA inspection had revealed that Ashikaga Bank had a negative net worth at the end of March 2003. Pursuant to Article 102-3 of the Deposit Insurance Law, the bank was nationalized. Depositors were protected but shareholders lost their stakes.

Ashikaga Bank, as a temporarily nationalized, carried out its operations and the DIC sought to transfer its business to an assuming financial institution. In March 2008, Nomura Holdings, the largest securities firm, bought the Bank from the government.

\section{Application of the DD to Banks ${ }^{11}$}

\subsection{Data}

In order to calculate the $\mathrm{DD}$, the following data are needed; the risk-free rate, the market value of equity, total assets (book value), stock holders' equity (book value), and short-term liability (book value). For the risk-free rate, the 3-month Saiken Gensaki rate (or the 3-month bond repurchase rate) is used from April 1, 1985 to May 31, 1992, while the 3-month Financial Bill (FB) rate is used after June 1, 1992. ${ }^{12}$ This is because

10 Official name of Financial Reconstruction Law is The Law Concerning Emergency Measures for the Reconstruction of the Functions of the Financial System.

11 Programs used in the paper were originally written by Dr. Kelly Wang and then modified by the authors. Kelly Wang was a coauthor of the authors' related work, Harada and Ito (2008).

12 A related paper, Nakajima and Souma (2008), uses the yen swap rate whose maturity is one year as the risk-free rate. We give consideration to the maturity of the short-term debts assumed in the model and choose the above mentioned risk-free rate. 
the FB rate is available only after June $1992 .{ }^{13}$ The market value of equity is defined by a daily stock price (closing price) times the number of issued stocks. When stock prices are not available, they are linearly interpolated. For the balance sheet data, unconsolidated statements are preferred since they represent stand-alone bank's financial health. ${ }^{14}$ The data, from April 1, 1985 to the day of each bank's delisting, were obtained from the Nikkei Financial Quest database. ${ }^{15}$ We follow Harada and Ito (2008) in defining what constitutes "short-term" liability.

For comparison, the DD of the "benchmark" bank was defined by the average of the five largest regional banks' DD; Chiba Bank, Yokohama Bank, Shizuoka Bank, Hiroshima Bank, and Fukuoka Bank. ${ }^{16}$ News which affects the entire banking sector is reflected in the benchmark bank as well as failed banks. The DD spread of each failed bank is defined by the DD of the failed bank minus the DD of the benchmark. The spread is considered to be reflecting bank-specific news.

\subsection{The Model}

The DD is calculated by a structural model of credit risk assessment pioneered by the option pricing theory of Merton (1974) and Black and Scholes (1973). The model defines a bank default when the market value of assets becomes below the book value of liabilities (the default point). The DD is defined by the number of the standard deviation of the market value of assets away from the default point. ${ }^{17}$ The larger the $\mathrm{DD}$, the greater is the distance of a company from the default point, and the lower is the

13 In the 1980s, the 3-month Saiken Gensaki rate was not available for several days. In this case, the most recent value is used instead.

14 For Ashikaga Bank, the unconsolidated data of Ashikaga bank is used until March 2003. The balance sheet data in March 2004 is not available for both the consolidated and unconsolidated data, and of both Ashikaga Bank and Ashigin Financial Group. Hence, the consolidated data of Ashigin Financial Group in March 2003 is used as the balance sheet data in March 2004 instead.

15 The exception is Hanwa Bank. The bank was listed on December 1, 1989.

16 These five banks were selected because their asset sizes were the largest among regional banks and they were regarded as sound banks. Large banks in asset size are not included in the benchmark bank as all large banks merged and were affiliated with financial holdings. Large banks are excluded due to the discontinuity in data and complicated merger process. See Harada and Ito (2008).

17 The definition of bank failure and types of measures for avoiding serious disruptions are officially defined in Article 102 of Deposit Insurance Law of May 2000. See Fukao (2007) and the Deposit Insurance Corporation Annual Reports. 
probability of default. For example, a DD of 2.0 means that default within a year is a two-standard deviation event, presuming the fluctuation of the market value of assets follows the recent historical value, using the current market value of assets as a starting point. Even if the DD becomes zero, it does not mean that the bank fails at that point of time. If short-term debts (liabilities with maturity less than a year) are not rolled over, then the bank would need to exhaust assets in order to repay within a year. The DD being 0.0 or even negative means that the bank will be highly likely to fail unless the asset value improves. However, if the short-term debts are rolled over, then the bank survives on the cash flow basis, although it is technically insolvent. In contrast, if short-term debts are called (time deposits withdrawn in a bank run), then it may fail at once. If and when the DD of a bank approaches zero, it implies the bank is in an extremely vulnerable position. In the event of a bank run, a sudden death may happen for the shortage of liquidity.

The option pricing theory determines the asset value and its volatility of a company from the observed stock prices and their volatility. Specifically, the value and the volatility of assets are calculated with Black and Scholes (1973)'s model by using the value and volatility of stock prices. Once the market value of assets and its volatility are known, it is possible to calculate the probability with which the asset value declines to the default point within a specified time. This probability is the probability of default and it corresponds one to one with the DD.

Since the DD is a market-based measure of distress, it contains expectations of market participants and it is forward-looking. Gropp, Vesala and Vulpes (2006) and Gropp amd Moerman (2004) argue that the DD may be a particularly suitable and all-encompassing measure of default risk for banks.

The DD is defined as follows:

$D D_{t}=\frac{\log \left(\frac{V_{t}}{L_{t}}\right)+\left(\mu_{A}-\frac{1}{2} \sigma_{A}^{2}\right) T}{\sigma_{A} \sqrt{T}}$,

where $V_{t}$ is the market value of the bank's assets at time t, $L_{t}$ is the bank's liability at time $\mathrm{t}$ (the default point), $\mu_{A}$ is the mean growth rate of $V_{t}, \sigma_{A}$ is the standard deviation of $\mu_{A}$, and $\mathrm{T}$ is a time horizon, which is set to one year. ${ }^{18}$ This assumption

18 The DD can be given either by using calculated $\mu_{A}$ or using the risk-free rate instead of $\mu_{A}$. Papers, such as Duffie et al.(2007), Vassalou and Xing (2004), Crosbie and Bohn (2003) and Harada and Ito (2008), estimate $\mu_{A}$ and use the value in the calculation of the DD. On the other hand, Gropp, Vesala and Vulpes (2006) and Nakashima and Souma (2008) use the risk-free rate 
is common when information about the maturity structure of liabilities is not available. If $L_{t}$ does not change until $t+T$ (i.e. $L_{t}=L_{t+T}$ ), we can interpret the numerator of $D D_{t}$ as $E_{t}\left(\log V_{t+T}-\log L_{t+T}\right)$. This is because $V_{\mathrm{t}}$ follows a geometric Brownian motion with mean $\mu_{\mathrm{A}}$ and standard deviation $\sigma_{\mathrm{A}}$, and hence $\log V_{t+T}$ is distributed as $N\left(\log V_{t}+\left(\mu_{A}-\frac{1}{2} \sigma_{A}^{2}\right) T, \sigma^{2} T\right) \cdot \cdot^{19}$

Therefore, the DD is also expressed as follows:

$D D_{t}=\frac{E_{t} \log \left(V_{t+T}\right)-\log L_{t+T}}{s t d\left(\log \left(V_{t+T}\right)\right)}$,

where $s t d()$ is the standard deviation. Hence, $D D_{t}$ and the default probability of the structural model correspond to each other one for one. These assumptions and the model's structure mean that a negative DD implies $E_{t}\left(\log V_{t+T}\right)<\log L_{t+T}$. As the market value of the assets follows the logarithmic normal distribution, a negative DD means that the probability of default $\left(V_{t+T}<L_{t+T}\right)$ at time $\mathrm{t}+\mathrm{T}$ is greater than 0.5 .

The $D D_{t}$ is calculated from the data as follows; $L_{t}$ is obtained from the bank's balance sheet and $\mathrm{T}$ is set equal to one year. In order to estimate $V_{t}, \mu_{A}$, and $\sigma_{A}$, we use Black and Scholes's option pricing model.

$$
\begin{aligned}
& W_{t}=V_{t} \Phi\left(d_{1}\right)-L_{t} e^{-r T} \Phi\left(d_{2}\right) \\
& \sigma_{A}=s t d\left(\ln \left(V_{t}\right)-\ln \left(V_{t-1}\right)\right)
\end{aligned}
$$

where

$$
\begin{aligned}
& d_{1}=\frac{\log \left(\frac{V_{t}}{L_{t}}\right)+\left(r+\frac{1}{2} \sigma_{A}^{2}\right) T}{\sigma_{A} \sqrt{T}} \\
& d_{2}=d_{1}-\sigma_{A} \sqrt{T}
\end{aligned}
$$

(See Appendix A for detail). Using $\mu_{A}$ is more suitable as assets are managed at a fluctuating interest rate rather than the risk free rate. This is why we use $\mu_{A}$.

$$
\begin{aligned}
& 19 E_{t}\left(\log V_{t+T}-\log L_{t+T}\right) \text { is derived as follows; } \\
& E_{t}\left(\log V_{t+T}-\log L_{t+T}\right)=E_{t}\left(\log V_{t+T}-\log L_{t}\right) \\
& =\log V_{t}+\left(\mu_{A}-\frac{1}{2} \sigma_{A}^{2}\right) T-\log L_{t} \\
& =\log \left(\frac{\mathrm{V}_{\mathrm{t}}}{\mathrm{L}_{\mathrm{t}}}\right)+\left(\mu_{A}-\frac{1}{2} \sigma_{A}^{2}\right) T \text {. }
\end{aligned}
$$


Here, $r$ is the risk-free rate, $W_{t}$ is the market value of equity (stock prices times the number of shares outstanding), $\Phi$ is the standard normal cumulative distribution function. In order to estimate $V_{t}, \mu_{A}$, and $\sigma_{A}$, we use the following steps. First, we set the initial guess for $V_{t}^{0}, V_{t-1}{ }^{0}, \ldots, V_{t-T+1}{ }^{0}$ (the previous year's data), then calculate $\sigma^{0}{ }_{A}$, using equation (4). We next calculate $V_{t}{ }^{1}, V_{t-1}{ }^{1}, \ldots, V_{t-T+1}{ }^{1}$ with $\quad \sigma^{0}{ }_{A}$. We then calculate $\sigma^{1}{ }_{A}$, using equation (4) and estimate $V_{t}^{2}, V_{t-1}{ }^{2}, \ldots, V_{t-T+1}{ }^{2}$ using $\sigma^{1}{ }_{A}$. We repeat these steps until the values converge.

In order to compute the DD of a bank, we need the book values of short-term and long-term debts. The banking sector, however, has a balance-sheet structure that is different from non-financial companies. We take industry-specific variables into consideration to classify a bank's debts into the short-term and long-term debts (See Appendix table 1). Items are in principle selected in terms of their maturity. Nevertheless care is needed. For example, even term deposits (of maturity more than a year) can be withdrawn if depositors forego a part of accrued interest, and so it could become short-term debt in the case of a bank run. ${ }^{20}$ We have to make several judgments in defining short-term debts.

\section{Empirical Results}

\subsection{Movements during the 6 Months Prior to Failure}

This subsection reports the DD of failed banks and illustrates how they have fluctuated since the late 1980s, in particular, for the last 6 months before the respective bank failure. Our interest is whether the DD is a good measure in predicting bank failures. The DD of failed banks over the whole period is illustrated in Figures 1 to 8, including the DD spread, the DD of failed banks minus the DD of the benchmark. Before examining those figures, the banks are divided into two groups, the banks explained by the DD and banks not explained by the DD, based on Tables 3 and 4, which show both the DDs and the DD spreads of the last 6 months before each failure, respectively.

Our explicit criterion is whether the DD has been gradually falling and

${ }^{20}$ Interim (a minor of the semi-annual) financial statements of Japanese companies do not contain detailed sub-items of time deposits and hence it is impossible to treat total debt minus time deposits as short-term debt. 
became very low before the news of the failure came out. Looking at the DD of the last 6 months in Table 3, the DD is a good measure for the cases of HTB, LTCB, Hyogo Bank and Hanwa Bank. The DD spreads implied that failed banks had been weaker than the benchmark banks and became weaker towards the failure as the DD spread of failed banks became negative and was falling steadily towards the failure.

HTB, LTCB, Hyogo Bank and Hanwa Bank are classified in the banks explained by the DD and the rest are in the banks not explained by the DD although the DD spread predicted most of the failures.

\section{Tables 3 and 4 are about here}

\subsection{Banks Explained by the DD}

The DDs are illustrated in Figures 1, 2, 4 and 6 for the banks explained by the DD. The DDs of those banks were positive and relatively stable during the bubble period in the late 1980s. What is interesting is that the DDs of failed banks were higher than that of the benchmark during the period. This finding suggests that failed banks performed very well during the bubble period.

Figures 1, 2, 4 and 6 about here

After the bubble period, the DD of the banks that would fail later declined sharply and became negative. Although the DD of the benchmark also declined, the DD of failed banks dropped more significantly than the benchmark. This implies that the failed banks were damaged more severely by the bursting of the bubble economy. While they experienced a recovery in their DD in 1993, they declined again after that. The DD of HTB (Figure 1) started to fall in the second half of 1993, whereas the DD of LTCB (Figure 2) started to dropped significantly only after 1997. Two regional banks, Hyogo Bank and Hanwa Bank, showed different patterns. Hyogo Bank (Figure 4) did not show a recovery in 1993 and the DD kept falling during the 1990s until the bank ultimately failed. Hanwa Bank (Figure 6) was listed in the second section of the Osaka Stock Exchange in December 1989 and their DD was close to zero from the beginning and did not show any improvement (there was a slight recovery period in mid 1995 but this was short-lived).

The DD seems to be a good measure in predicting failures for banks in this subsection. As for HTB, the bank announced its failure on November 17, 1997 and 
then the DD dropped sharply, but it had been gradually falling before the announcement. Although the DD improved slightly during 1995-1996, it had started to decline in 1993 and reached below -2 at the time of the announcement. The same pattern is observed for LTCB. The bank announced its failure on October 23, 1998, but the DD had been gradually declining since 1996. The DDs of Hyogo Bank and Hanwa Bank also kept falling during the 1990s until they failed. From these observations, we may conclude that for HTB, LTCB, Hyogo Bank, and Hanwa Bank, the DD was a good measure in predicting the failure.

\subsection{Banks Whose Failures were Not Explained by the DD}

Banks in this group are illustrated in Figures 3, 5, 7 and 8. The DD was not a good measure in predicting their failure; the DD did not fall or become significantly low before the news on their failure was made public. These banks are NCB (Figure 3), Taiheiyo Bank (Figure 5), Tokyo Sowa Bank (Figure 7), and Ashikaga Bank (Figure 8). Those banks have unique reasons for unreliable DD as a predictor of bank failure.

\section{Figures 3, 5, 7 and 8 about here}

The DD of NCB (Figure 3) fluctuated widely, but did not decline sharply until the announcement of the bank failure. NCB announced a temporary nationalization on December 12, 1998, but the DD had been increasing during the days before the announcement day. The market was not aware of the process of inspection by the regulatory authorities. Moreover, as we explained, selling pressure was less due to a restriction in that newly issued stocks could not be sold.

As for failed regional banks, the DD had not fallen significantly before the announcement. For Taiheiyo Bank (Figure 5), Tokyo Sowa Bank (Figure 7) and Ashikaga Bank (Figure 8), the DDs and the DD spreads of the banks fluctuated widely and the DDs were almost always lower than that of the benchmark but no other common pattern was found. For Taiheiyo Bank, the DD spread, the DD of failed banks minus that of the benchmark, seemed to be a reliable measure in predicting their failure. The DD spread had become negative prior to the announcement day. In the cases of NCB, Tokyo Sowa Bank, and Ashikaga Bank, the DD spread, as well as the DD itself, was not a good measure in predicting their failure; neither the DD nor the DD spread declined sharply before the announcement of their failure. However, the result is not surprising. For instance, both NCB and Ashikaga Bank were inspected by the FSA, 
who then found that these banks were insolvent. This implies that the banks did not disclose important information and thus the market was not able to respond appropriately. The DD is a market-based measure of default risk, so lack of predictability of bank failure implied lack of public information in the market. Hence, the lack of transparency was to blame for market participants' surprise.

It is suggested that the DD could be a helpful measure in predicting bank failures although the DD cannot deal with exceptional cases that arise from lack of timely information. In addition, the DD spread also helps to predict bank failures.

\section{Conclusion}

This paper examines the DDs of failed Japanese banks. Investigating eight Japanese failed banks, it is found that the DD was generally a reliable measure in predicting bank failures. The DD spread was also a helpful measure. For some banks neither the DD nor the DD spread predicted the failures. However, those results were partly due to lack of transparency in financial statements and disclosed information.

The following task is left for future research. Since some studies examine other indicators, such as credit ratings, outstanding of NPLs and the capital adequacy ratio, in order to evaluate bank health, it is important to examine whether and how the DD and these indicators are related. In addition, it should be examined whether reforms in the banking regulating policy and the supervisory system during the 1990s have affected the behavior of the DDs. In order to compare the DDs of failed banks, the benchmark, the average DD of regional banks, is used in this paper. It might be desirable to calculate the DD of many other banks, including banks that experience organizational restructuring or capital tie-ups in order to draw a stronger conclusion. Bank failures are examined in many papers, but research using DD seems to be a promising direction, based on this paper. 


\section{Reference}

Black, Fisher and Myron Scholes (1973), "The Pricing of Options and Corporate Liabilities," Journal of Political Economy 81(3), 637-654.

Brewer, Elijah III, Hesna Genay, Williamu C. Hunter, and George G. Kaufman (2003), "Does the Japanese Stock Market Price Bank-Risk? Evidence from Financial Firm Failures,” Journal of Money, Credit and Banking 35 (4), 507-543.

Cargill, Thomas F., Michael M. Hutchison, and Takatoshi Ito (1997), The Political Economy of Japanese Monetary Policy, MIT Press.

Cargill, Thomas F., Michael M. Hutchison, and Takatoshi Ito (2000), Financial policy and Central Banking in Japan, MIT Press.

Chan-Lau, Jorge A., Srobona Mitra, and Li Lian Ong (2007), "Contagion Risk in the International Banking System and Implications for London as a Global Financial Center," IMF Working Paper 07/74.

Chan-Lau, Jorge A. and Amadou N.R. Sy (2007), "Distance-to-Default in Banking: A Bridge Too Far?," Journal of Banking Regulation, 9(1), 14-24.

Crosbie, Peter, and Jeff Bohn (2003), “Modeling Default Risk,” Moody's KMV White Paper, (San Francisco: Moody's Investor Service) December 18.

Danmarks National Bank (2004), Financial Stability Report (Copenhagen). Available via the internet at http://www.nationalbanken.dk

Deposit Insurance Corporation of Japan, “Annual Report 2005," “Annual Report 2006”.

De Nicolo, Gianni, and Alexander Tieman (2006), "Economic Integration and Financial Stability: A European Perspective", IMF Working Paper 05/296.

Duffie, Darrell, Leandro Saita and Ke Wang (2007), "Multi-period Corporate Default Prediction with Stochastic Covariates," Journal of Financial Economics, 83(3), 635-665. 
Duggar, Elena and Srobona Mitra (2007), "External Linkages and Contagion Risk in Irish Banks,” IMF Working Paper 07/44.

European Central Bank (2005), Financial Stability Review, June (Frankfurt).

Fukao, Mitsuhiro (2007), "Financial Crisis and the Lost Decade," Asian Economic Policy Review, 2, 273-297.

Gropp, Reint, Marco Lo Duca and Jukka Vesala (2006), "Cross-Border Bank Contagion in Europe," European Central Bank Working Paper Series 662.

Gropp, Reint, Jukka Vesala and Giuseppe Vulpes (2006), "Equity and Bond Market Signals as Leading Indicators of Bank Fragility," Journal of Money, Credit and Banking, 38(2), 399-428.

Hanajiri, Tetsuro (1999), "Three Japan Premiums in Autumn 1997 and Autumn 1998 - Why Did Premiums Differ between Markets?" Financial Markets Department Working Paper, No. 99-E-1, Bank of Japan.

Harada, Kimie and Takatoshi Ito (2008), "Did Merger Help Japanese Mega-Banks Avoid Failure? Analysis of the Distance to Default of Banks," NBER Working Paper Series 14518.

Hoshi, Takeo and Hugh Patrick (2000), "The Japanese Financial System: An Introductory Overview," in Crisis and Change in the Japanese Financial System, Kluwer Academic Publishers.

Hoshi, Takeo and Anil Kashyap (2001), Corporate Financing and Governance in Japan: The Road to the Future, MIT Press, Cambridge, Mass.

Hoshi, Takeo and Takatoshi Ito (2004), "Financial regulation in Japan: a sixth year review of the Financial Services Agency", Journal of Financial Stability, 1, 229-243.

Ito, Takatoshi (2000), "The Stagnant Japanese Economy in the 1990s: The Need for Financial Supervision to Restore Sustained Growth," in Crisis and Change in the Japanese Financial System, Kluwer Academic Publishers. 
Ito, Takatoshi and Kimie Harada (2004), "Credit Derivatives Premium as a New Japan Premium," Journal of Money, Credit and Banking, 36(5), 965-968.

Ito, Takatoshi and Kimie Harada (2005), "Japan Premium and Stock Prices: Two Mirrors of Japanese Banking Crises," International Journal of Finance \& Economics, 10(3), 195-211.

Ito, Takatoshi and Kimie Harada (2006), "Bank Fragility in Japan: 1995-2003," in Japan's Great Stagnation: Financial and Monetary Policy Lessons for Advanced Economies edited by Michael Hutchison and Frank Westermann, the MIT Press Inc.

Ito, Takatoshi and Yuri Nagataki Sasaki, (2002). "Impacts of the Basle Capital Standard on Japanese Banks' Behavior” Journal of the Japanese and International Economies, vol. 16, September: 372-397.

Merton, Robert C. (1974), "On the Pricing of Corporate Debt: the Risk Structure of Interest Rates," Journal of Finance 29, 449-470.

Nakashima, Kiyotaka and Toshiyuki Souma (2008), "Firm Fragility Measures and the Effect of Public Fund Injections in Japan,” mimeograph

Okada, Tae (2007), “Consequences of Bank Mergers [Ginko gappei no kouka, in Japanese], mimeograph.

Peek, Joe and Eric S. Rosengren (2001), "Determinants of the Japan Premium: Actions Speak Louder than Words," Journal of International Economics, 53(2), 283-305.

Sakuragawa, Masaya and Yoshitsugu Watanabe (2007), "Did the Japanese Stock Market appropriately Price the Takenaka financial reform?" presented at the NBER $18^{\text {th }}$ EASE conference.

Spiegel, Mark and Nobuyoshi Yamori (2003), "The Impact of Japan's Financial Stabilization Laws on Bank Equity Values," Journal of Japanese and International Economies 17(3), 263-282.

Spiegel, Mark and Nobuyoshi Yamori (2004), "The Evolution of Bank Resolution Policies in 
Japan: Evidence from Market Equity Values," Journal of Financial Research, 1, 115-132.

Vassalou, Maria, and Yuhang Xing (2004), "Default Risk in Equity Returns", Journal of Finance, 59, 831-868.

Ueno, Yoichi and Baba Naohiko (2006), "Default Intensity and Expected Recovery of Japanese Banks and "Government" : New Evidence from the CDS Market," Bank of Japan Working Paper, No.06-E-4. 
Table 1 Failed Banks

\begin{tabular}{|c|c|c|c|}
\hline Bankruptcy date & Name of bank & Type of failure & Transfer of business, contractual transfer or current name \\
\hline $1995 / 8 / 30$ & Hyogo Bank & $\begin{array}{l}\text { Announcement of the failure by the Ministry of } \\
\text { Finance }\end{array}$ & Midori Bank (later Minato Bank) \\
\hline $1996 / 3 / 29$ & Taiheiyo Bank & Announcement of the disposal plan & Wakashio Bank (Newly-established bank by Sakura Bank) \\
\hline $1996 / 11 / 21$ & Hanwa Bank & $\begin{array}{l}\text { Ordered suspension of business by the } \\
\text { authorities }\end{array}$ & Kii Deposits Management Bank \\
\hline $1997 / 10 / 14$ & Kyoto Kyoei Bank & Transfer of business & Kofuku Bank (later bankrupt) \\
\hline $1997 / 11 / 17$ & $\begin{array}{l}\text { Hokkaido } \\
\text { Takushoku Bank }\end{array}$ & Transfer of business & Hokuyo Bank and Chuo Trust \&Banking \\
\hline $1997 / 11 / 26$ & Tokuyo City Bank & Transfer of business & The 77 Bank and Sendai Bank \\
\hline $1998 / 5 / 15$ & Midori Bank & Transfer of business & Hanshin Bank \\
\hline $1998 / 5 / 22$ & Fukutoku Bank & Transfer of business & Namihaya Bank (Newly-established by the government. Later bankrupt.) \\
\hline $1998 / 5 / 22$ & Naniwa Bank & Transfer of business & Namihaya Bank (Newly-established by the government. Later banklupt.) \\
\hline $1998 / 10 / 23$ & $\begin{array}{l}\text { Long-Term Credit } \\
\text { Bank of Japan }\end{array}$ & $\begin{array}{l}\text { Decision to commence special public } \\
\text { management and the government purchase of }\end{array}$ & $\begin{array}{l}\text { Transfer and purchase of shares to New LTCB Partners. Now Shinsei } \\
\text { Bank }\end{array}$ \\
\hline $1998 / 12 / 12$ & Nippon Credit Bank & $\begin{array}{l}\text { Decision to commence special public } \\
\text { management and the government purchase of }\end{array}$ & $\begin{array}{l}\text { Transfer and purchase of shares to Softbank Group (consisted of } \\
\text { Softbank, Orix and Tokio Marine). Now Aozora Bank }\end{array}$ \\
\hline $1999 / 4 / 11$ & Kokumin Bank & Announcement of failure & Yachiyo Bank \\
\hline $1999 / 5 / 21$ & Kofuku Bank & File for disposal & Kansai Sawayaka Bank \\
\hline $1999 / 6 / 11$ & Tokyo Sowa Bank & File for disposal & Tokyo Star Bank \\
\hline $1999 / 8 / 6$ & Namihaya Bank & File for disposal & Daiwa Bank and Kinki Osaka Bank \\
\hline $1999 / 10 / 1$ & Niigata Chuo Bank & File for disposal & $\begin{array}{l}\text { Taiko Bank, Daishi Bank, Hachijuni Bank, Higashi-Nippon Bank, } \\
\text { Gunma Bank and Towa Bank }\end{array}$ \\
\hline $2001 / 12 / 28$ & Ishikawa Bank & File for disposal & $\begin{array}{l}\text { (Through Bridge Bank of Japan) Hokuriku Bank, Hokkoku Bank, The } \\
\text { First Bank of Toyama, Kanazawa Shinkin Bank and Noto Shinkin Bank }\end{array}$ \\
\hline $2002 / 3 / 7$ & Chubu Bank & File for disposal & $\begin{array}{l}\text { (Through Bridge Bank of Japan) Shimizu Bank, Shizuoka Chuo Bank } \\
\text { and Tokyo Star Bank }\end{array}$ \\
\hline $2003 / 11 / 29$ & Ashikaga Bank & Temporalily nationalized & $\begin{array}{l}\text { Nomura Financial Partners (Nomura Holdings) and Next Capital } \\
\text { Partners Co., Ltd., acquired all outstanding shares of Ashikaga Bank }\end{array}$ \\
\hline
\end{tabular}


Table2 : The DIC assisted mergers and loss-covers

\begin{tabular}{|c|c|c|c|c|c|c|}
\hline \multirow{2}{*}{$\begin{array}{l}\text { Fiscal year } \\
\text { (ending on } \\
\text { March 31) }\end{array}$} & \multirow{2}{*}{$\begin{array}{c}\text { Number of failed } \\
\text { institutions }\end{array}$} & \multirow{2}{*}{$\begin{array}{c}\text { Financial } \\
\text { assistance } \\
\text { (million yen) }\end{array}$} & \multicolumn{4}{|c|}{ DIC (billion yen) } \\
\hline & & & Gross revenue & Expenditures & Net revenues & $\begin{array}{l}\text { Reserves at the } \\
\text { end of fiscal vear }\end{array}$ \\
\hline 1992 & 2 & 20,000 & 94,411 & 20,169 & 74,241 & 770,626 \\
\hline 1993 & 2 & 45,900 & 96,081 & 46,137 & 49,944 & 820,570 \\
\hline 1994 & 2 & 42,500 & 98,140 & 42,680 & 55,459 & 876,030 \\
\hline 1995 & 3 & 600,800 & 111,581 & 601,033 & $-489,452$ & 386,578 \\
\hline 1996 & 6 & $1,316,000$ & 532,743 & $1,314,428$ & $-781,684$ & $-395,106$ \\
\hline 1997 & 7 & 152,400 & 464,317 & 163,228 & 301,089 & $-94,017$ \\
\hline 1998 & 30 & $2,674,100$ & $1,675,820$ & $2,769,430$ & $-1,093,610$ & $-1,187,627$ \\
\hline 1999 & 20 & $4,637,400$ & $4,216,932$ & $4,926,059$ & $-709,127$ & $-1,896,755$ \\
\hline 2000 & 20 & $5,155,800$ & $4,204,983$ & $5,453,792$ & $-1,248,809$ & $-3,145,565$ \\
\hline 2001 & 37 & $1,641,500$ & $1,288,209$ & $1,940,875$ & $-652,666$ & $-3,798,231$ \\
\hline 2002 & 51 & $2,324,400$ & $2,502,074$ & $2,710,347$ & $-208,273$ & $-4,006,504$ \\
\hline 2003 & 0 & 0 & 742,728 & 230,070 & 512,657 & $-3,493,847$ \\
\hline 2004 & 0 & 0 & 656,581 & 139,783 & 516,798 & $-2,977,048$ \\
\hline 2005 & 0 & 0 & 740,157 & 218,034 & 522,122 & $-2,454,926$ \\
\hline 2006 & 0 & 0 & & & & \\
\hline
\end{tabular}

Source: Annual reports of the DIC. 
Table 3 The DD before Failures

\begin{tabular}{|l|r|r|r|r|r|r|r|}
\hline The DD & 6 months & 5 months & 4 months & 3 months & 2 months & 1 month & Failure \\
\hline Hokkaido Takushoku Bank & -2.27 & -2.12 & -2.35 & -2.59 & -2.83 & -2.62 & -3.29 \\
\hline LTCB & 0.44 & 0.20 & -1.88 & -2.34 & -2.10 & -3.29 & -5.01 \\
\hline NCB & 1.21 & 1.10 & 1.35 & 1.69 & 1.88 & 2.54 & 2.38 \\
\hline Hyogo Bank & -0.97 & -0.01 & -0.05 & -0.17 & -1.23 & 0.72 & 0.21 \\
\hline Taiheiyo Bank & 1.22 & 0.49 & 0.77 & 0.82 & 0.68 & 0.72 & -1.00 \\
\hline Hanwa Bank & -0.22 & -0.53 & -0.78 & -0.96 & -0.89 & -1.45 & -1.99 \\
\hline Tokyo Sowa Bank & 0.67 & 0.47 & 0.32 & 0.70 & 1.90 & 1.98 & -0.68 \\
\hline Ashikaga Bank & 2.04 & 3.32 & 2.35 & 2.27 & 2.43 & 1.15 & -1.23 \\
\hline Average & $\mathbf{0 . 2 4}$ & $\mathbf{0 . 3 6}$ & $\mathbf{- 0 . 0 3}$ & $\mathbf{- 0 . 0 7}$ & $\mathbf{- 0 . 0 2}$ & $\mathbf{- 0 . 0 3}$ & $\mathbf{- 1 . 3 3}$ \\
\hline
\end{tabular}

Table 4 The DD Spread before Failures

\begin{tabular}{|l|r|r|r|r|r|r|r|}
\hline The DD Spread & 6 months & 5 months & 4 months & 3 months & 2 months & 1 month & Failure \\
\hline Hokkaido Takushoku Bank & -3.28 & -3.30 & -3.71 & -3.36 & -3.34 & -2.86 & -3.35 \\
\hline LTCB & -0.29 & -0.45 & -2.35 & -2.78 & -2.56 & -3.83 & -5.70 \\
\hline NCB & 0.73 & 0.57 & 0.95 & 1.09 & 1.49 & 1.64 & 1.15 \\
\hline Hyogo Bank & -2.31 & -1.88 & -1.97 & -2.03 & -2.75 & -1.36 & -2.40 \\
\hline Taiheiyo Bank & -1.57 & -2.05 & -2.14 & -2.27 & -2.42 & -2.39 & -4.76 \\
\hline Hanwa Bank & -3.98 & -4.72 & -4.57 & -4.66 & -4.51 & -4.29 & -4.93 \\
\hline Tokyo Sowa Bank & -0.55 & -0.42 & -0.51 & -0.47 & -0.28 & -0.33 & -2.80 \\
\hline Ashikaga Bank & 0.48 & 1.64 & 0.89 & 0.84 & 0.73 & -1.11 & -3.45 \\
\hline Average & $\mathbf{- 1 . 4 0}$ & $\mathbf{- 1 . 3 7}$ & $\mathbf{- 1 . 6 9}$ & $\mathbf{- 1 . 7 2}$ & $\mathbf{- 1 . 7 0}$ & $\mathbf{- 2 . 0 1}$ & $\mathbf{- 3 . 2 8}$ \\
\hline
\end{tabular}


Figure 1 Hokkaido Takushoku Bank DD from 1986 to 1998

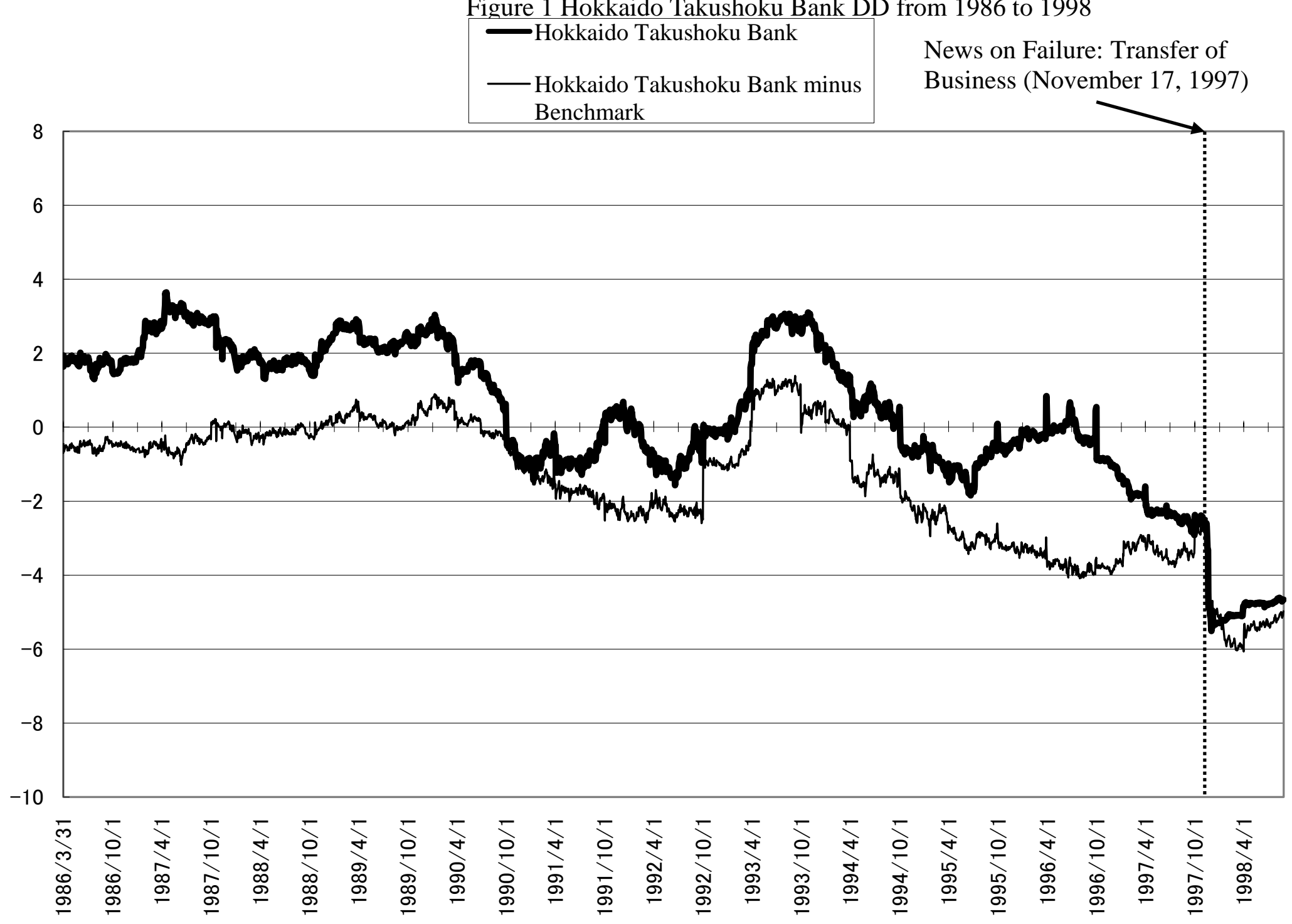


Figure 2 LTCB DD from 1986 to 1998

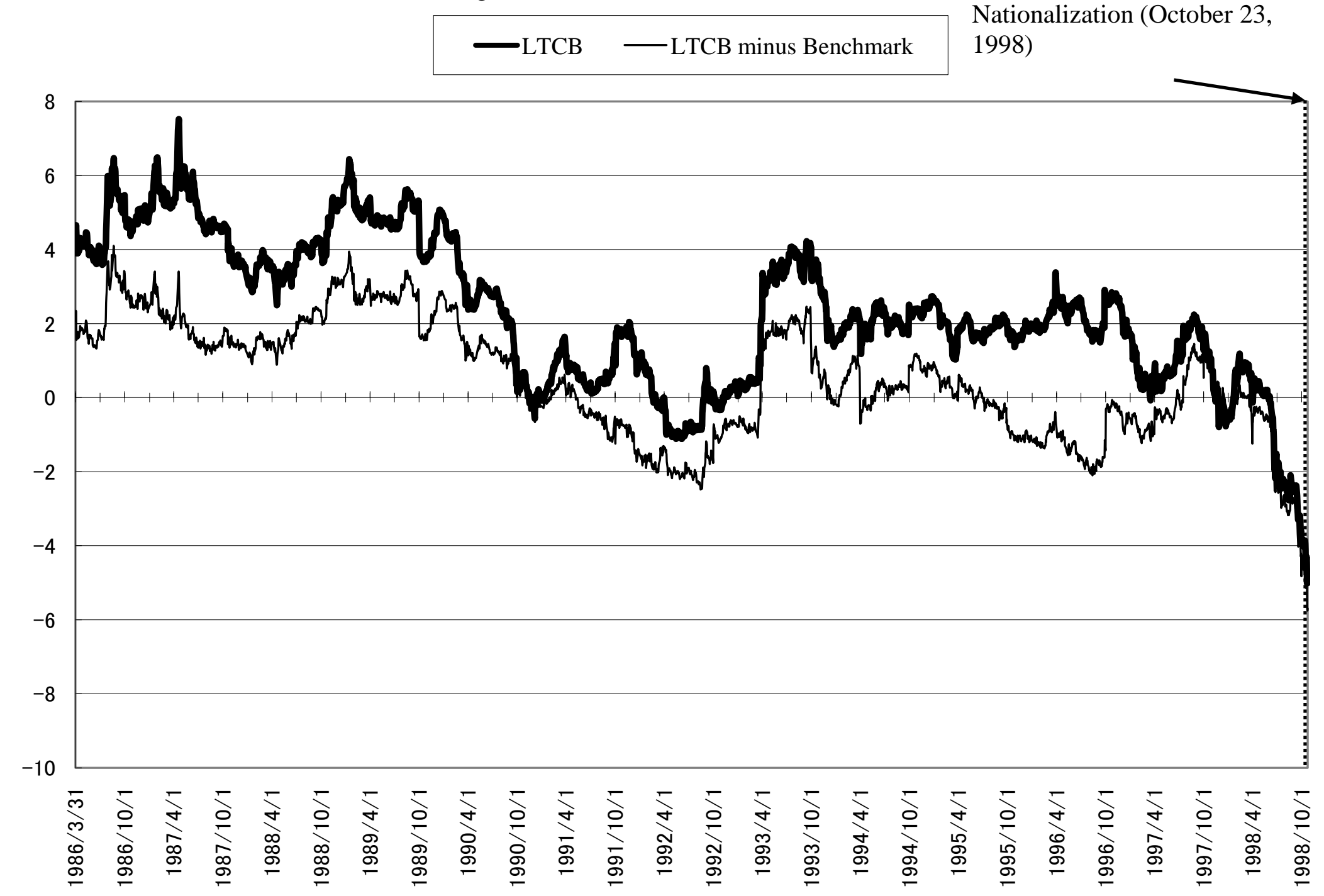


Figure 3 NCB DD from 1986 to 1998

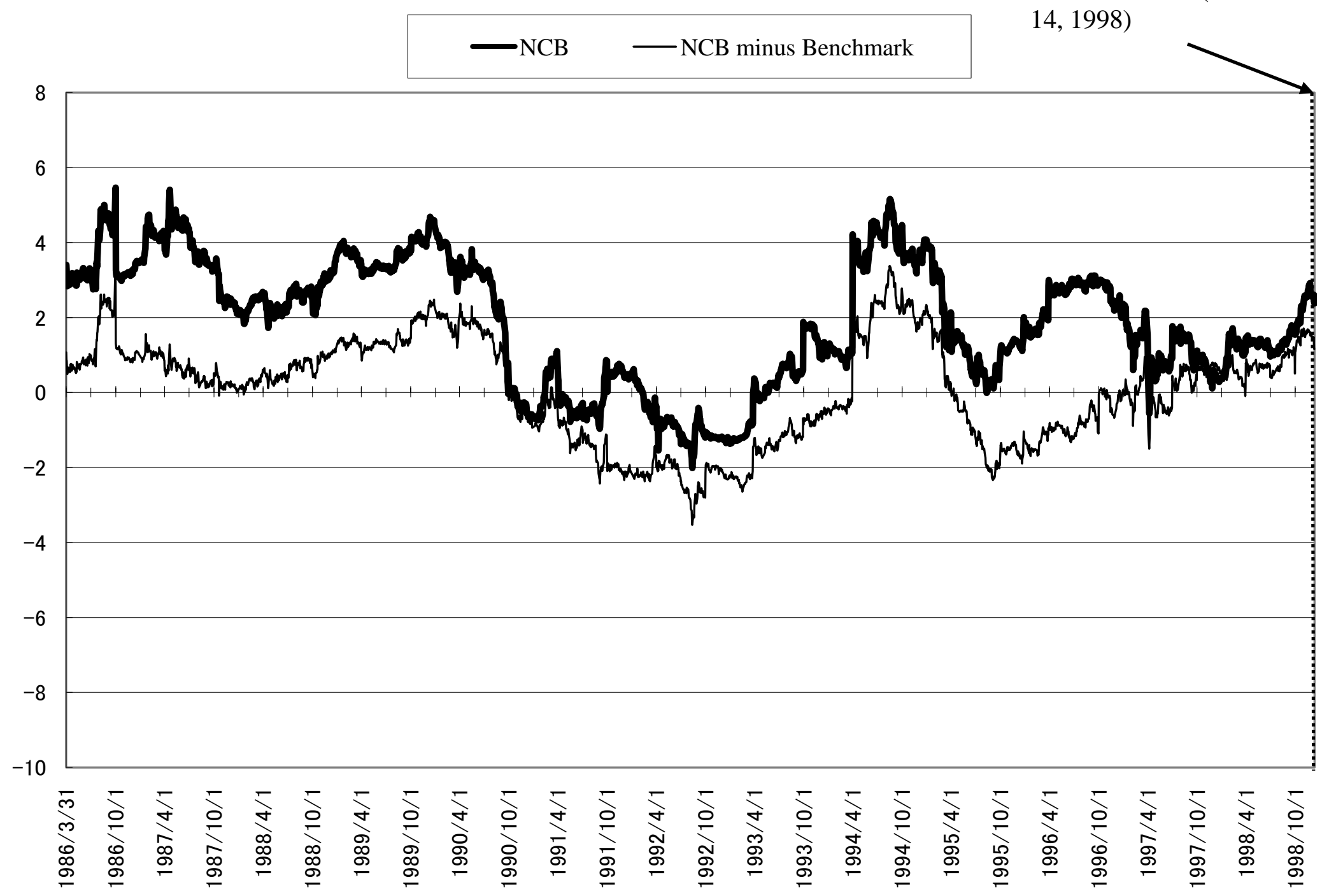
Nationalization (December 14, 1998)

News on Failure: Temporal 
Figure 4 Hyogo Bank DD from 1986 to 1996

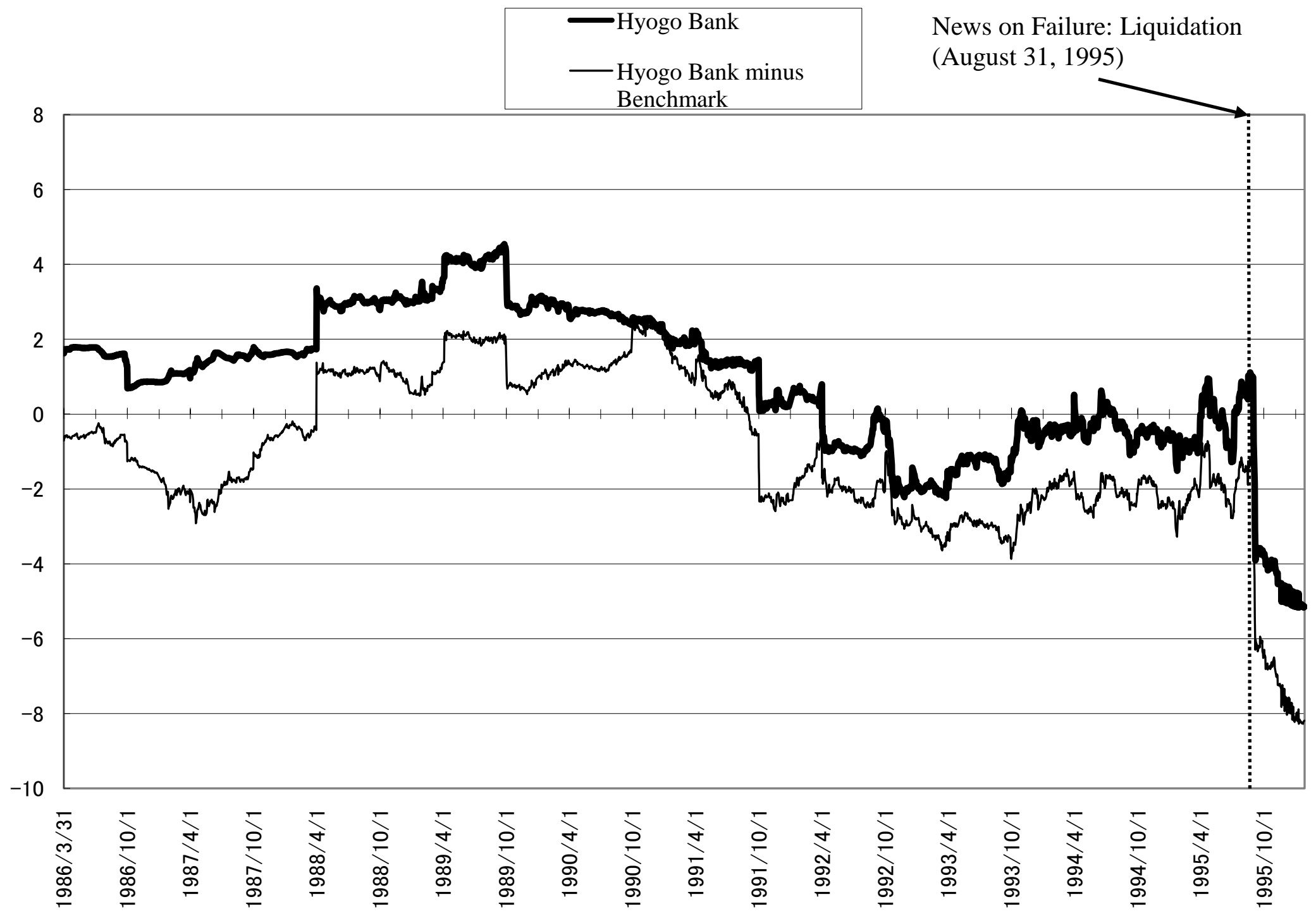




\section{Figure 5 Taiheiyo Bank DD from 1986 to 1996}

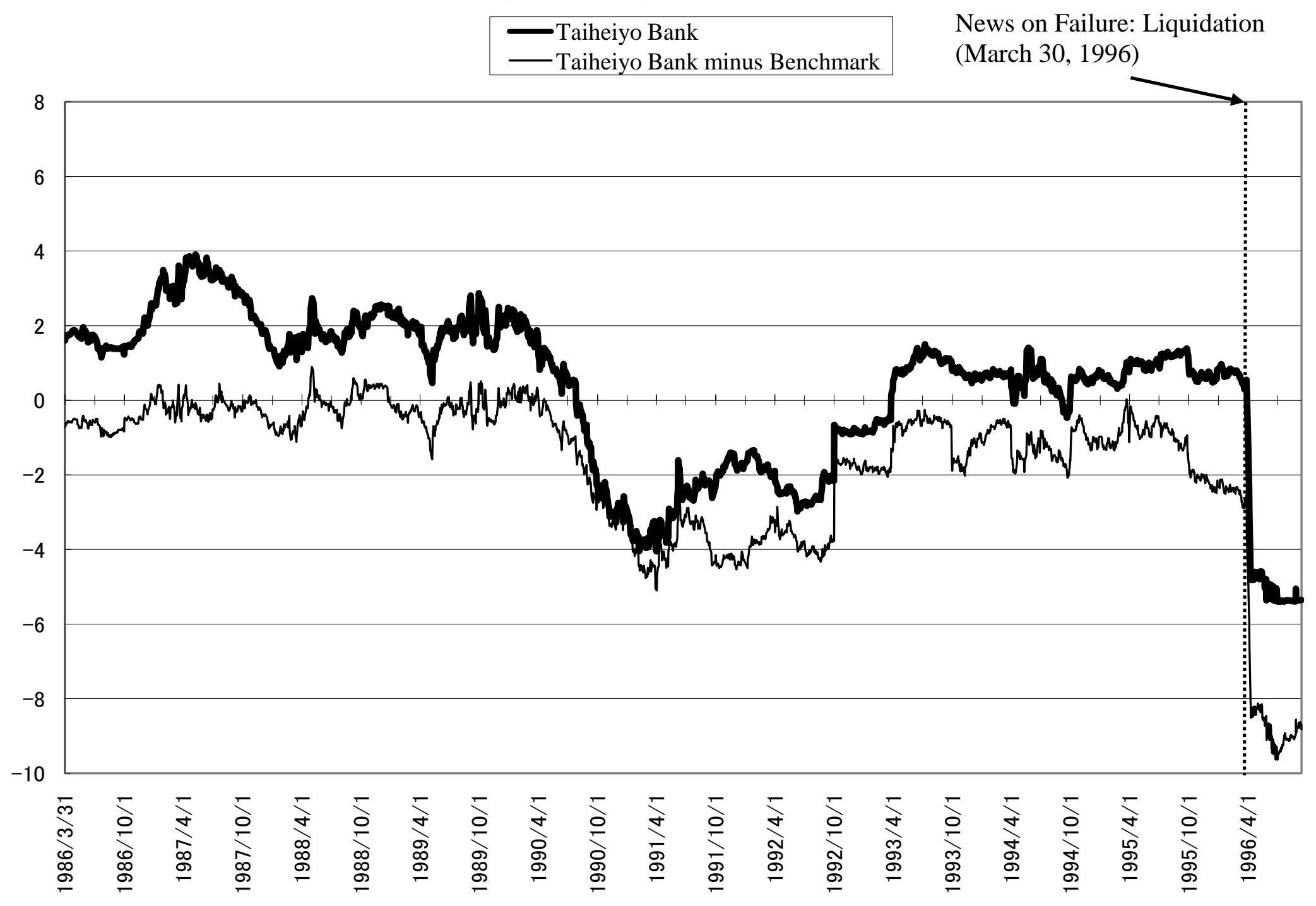


Figure 6 Hanwa Bank DD from 1990 to 1997

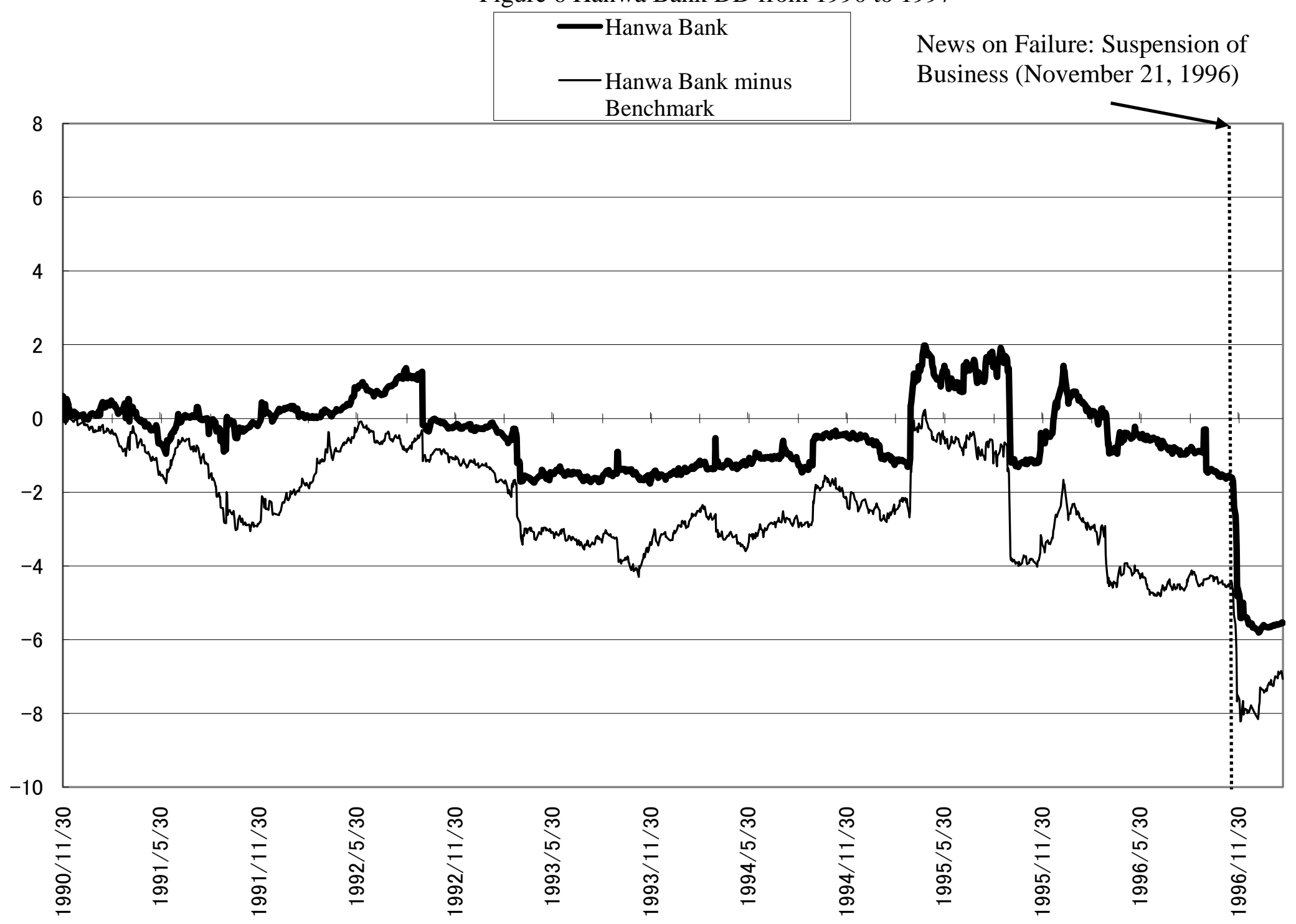


Figure 7 Tokyo Sowa Bank DD from 1986 to 1999

Tokyo Sowa Bank

Tokyo Sowa Bank minus Benchmark

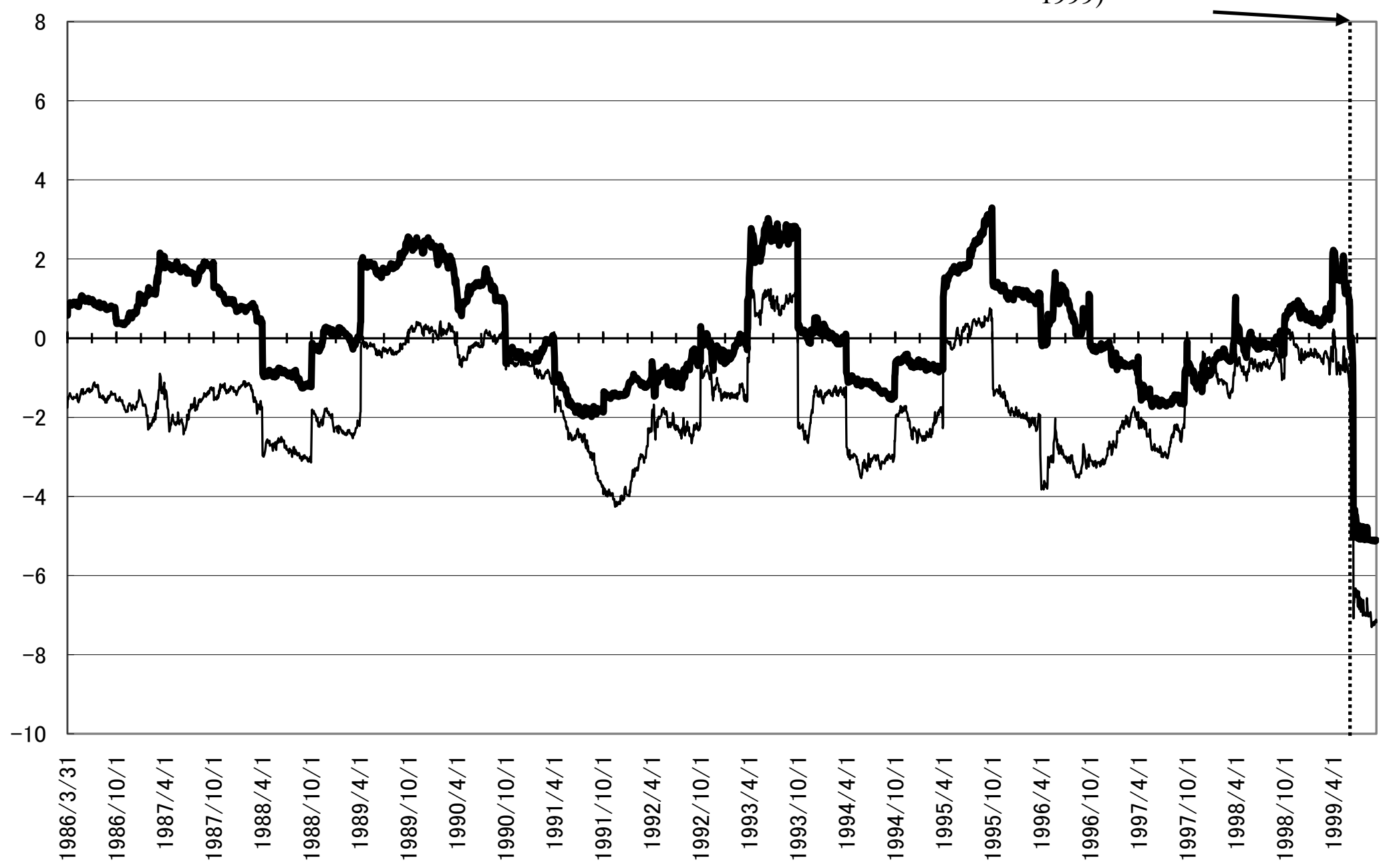

News on Failure: Filing for

Protection under DIL (June 12, 1999) 
Figure 8 Ashikaga Bank DD from 1986 to 2004

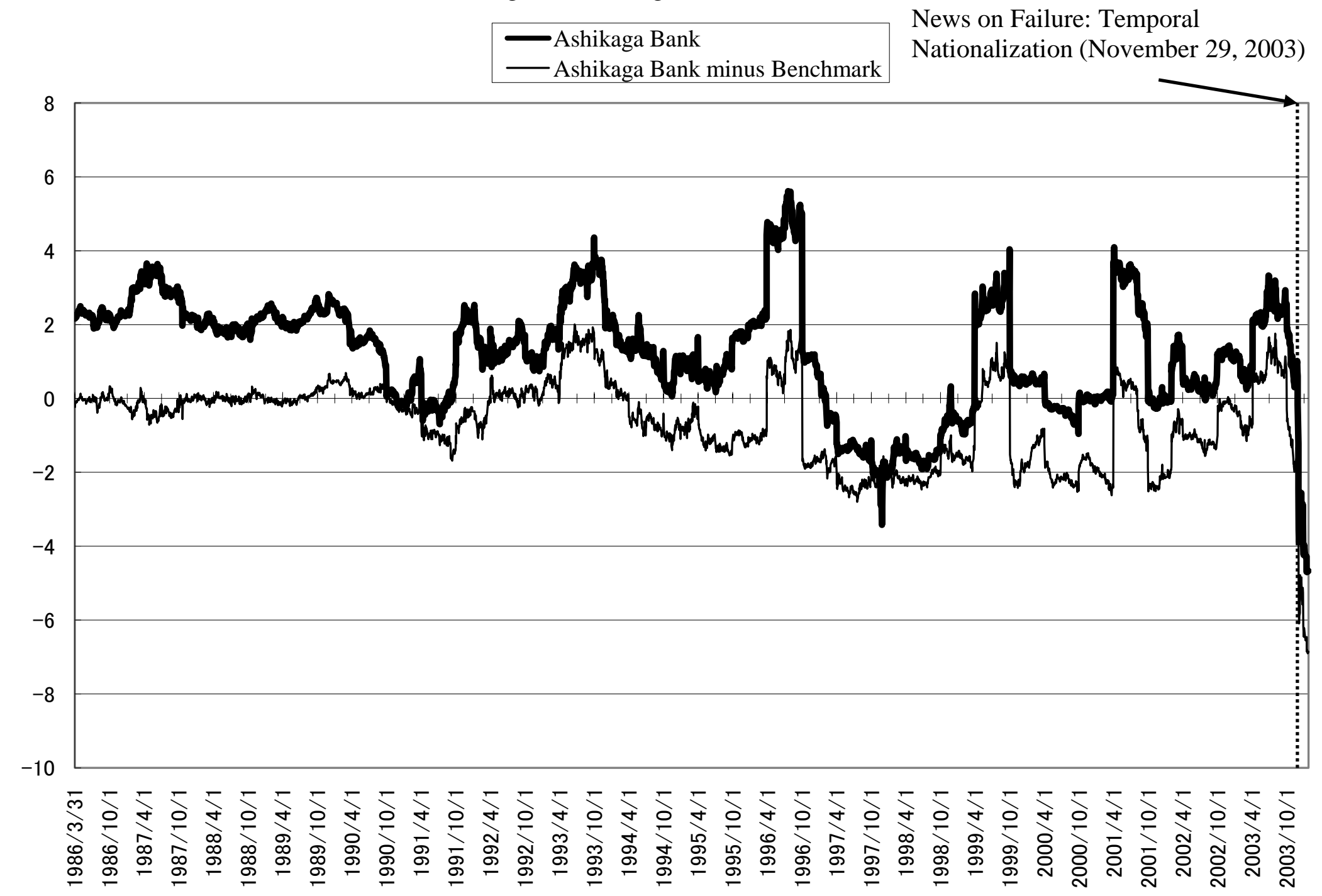




\section{Appendix A: Two Methodologies of Calculating the DD}

The definition of the DD is

$$
D D_{t}=\frac{\log \left(\frac{V_{t}}{L_{t}}\right)+\left(\mu_{A}-\frac{1}{2} \sigma_{A}^{2}\right) T}{\sigma_{A} \sqrt{T}}
$$

There are two methodologies to calculate the DD. Vassalou and Xing (2004), Duffie et al. (2007), Harada and Ito (2008) and this paper calculate the market value of assets at time t, $V_{t}$, using previous year's balance sheet data. That is, one year's information of the previous year is needed in order to calculate $\mu_{A}$ and $\sigma_{A}$, which are the mean growth rate of $V_{t}$ and the standard deviation of $\mu_{A}$ respectively. Meanwhile, Gropp et al. (2006) and Nakashima and Soma (2008) use the risk free rate instead of calculating $\mu_{A}$. For $\sigma_{A}$, they use the following equation:

$$
\sigma_{E}=\left(\frac{V_{t}}{E_{t}}\right) \Phi\left(d_{1}\right) \sigma_{A},
$$

where $E_{t}$ is the market value of equity capital (stock price times the number of shares outstanding) and $\sigma_{E}$ is its volatility. This calculation requires less historical data rather than the other methodology. As an example, Nakashima and Soma (2008) use stock price for 20 days prior to time $t$.

Calculating the DD with our methodology is time consuming however we believe it is better in terms of credibility. However, different types of the DDs and the DD spreads are presented below for comparison. The example bank shown here is Hokkaido Takushoku Bank. In the figure, "Standard" means the DD by the methodology used in Vassalou and Xing (2004), Duffie et al. (2007), Harada and Ito (2008) and this paper. "Gropp et al." means the DD by the second methodology which is calculating $\sigma_{E}$ from previous year's $E_{t}$. In addition, "Compromise" is the DD using the risk free rate instead of $\mu_{A}$ as the second methodology, "Gropp et al." does, but calculating $\sigma_{A}$ by the same way with "Standard".

The DDs in the figure move in the same direction to a large degree. This means that the usefulness of the DDs and the DD spreads do not improve significantly when the new methods are used (see Tables 3 and 4). However, our methodology evaluates the bank with strongest standard as the DD fell below zero in 1990 and in the middle of 1990s. The DD was negative for about a year ago before the bank bankrupted. While, the other DDs were rather stable. Using "Gropp et al.", we are not able to anticipate the bankruptcy in the case of Hokkaido Takushoku Bank. 


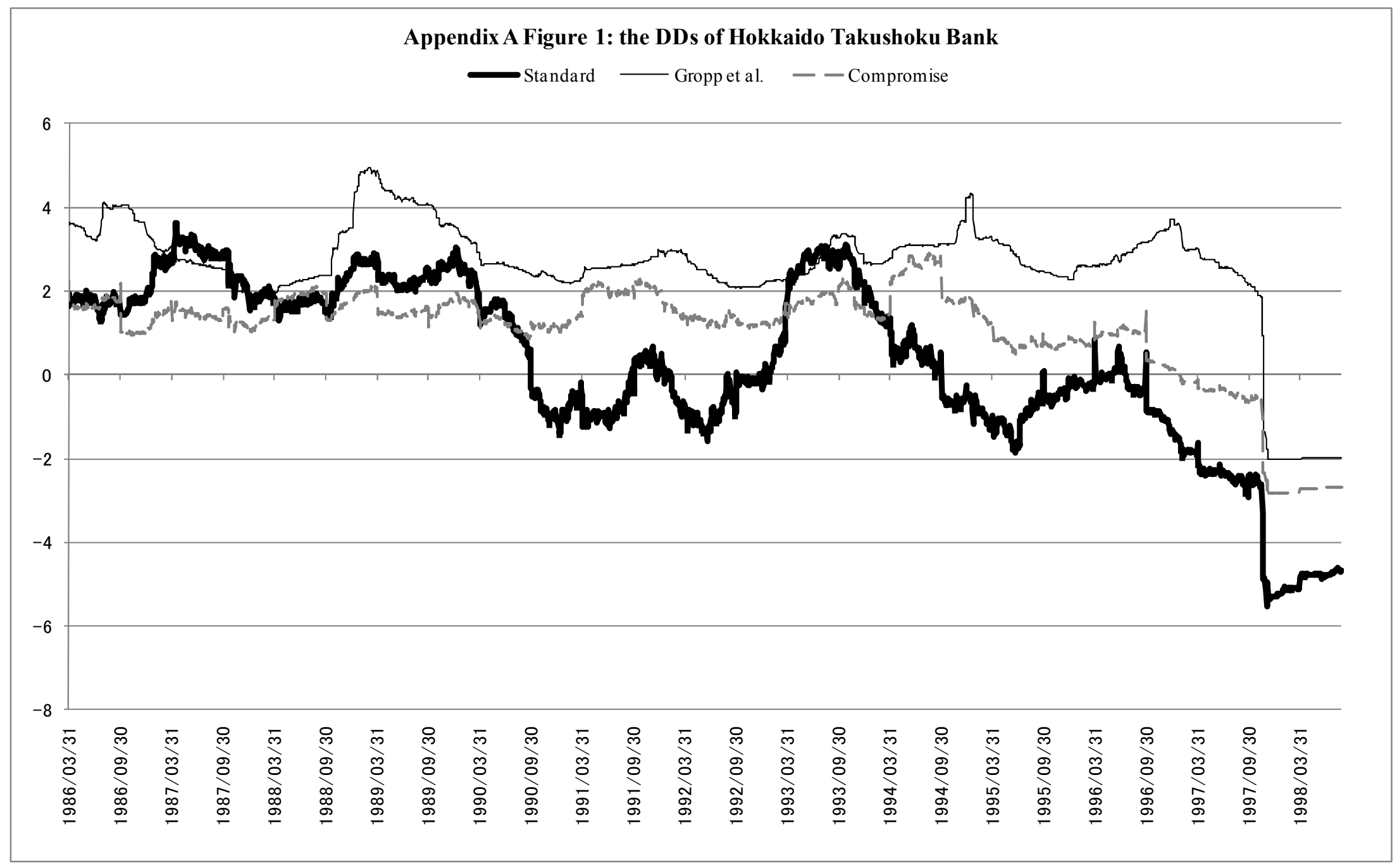




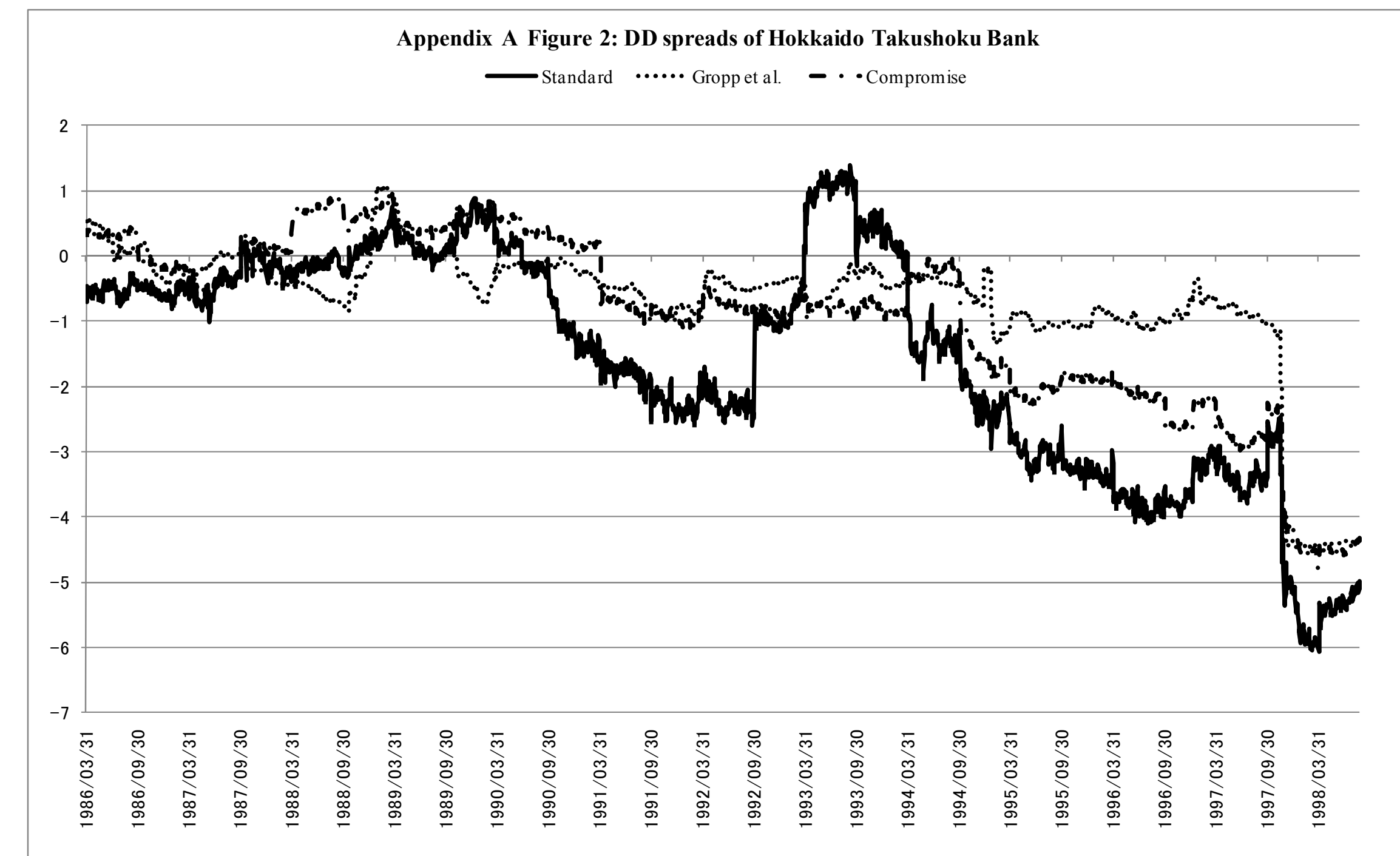




\section{Appendix Table1: Short term and long term liablity of banks}

\begin{tabular}{|l|l|}
\hline Short term liability & Long term liability \\
\hline Deposits & Debentures \\
\hline Negotiable certificates of deposit & Straight bonds \\
\hline Call money & \\
\hline Payables under repurchase agreements & Convertible bonds \\
\hline Payables under securities lending transactions & Due to trust accounts \\
\cline { 1 - 1 } Bills sold & \\
\cline { 1 - 1 } Commercial papers & \\
\cline { 1 - 1 } Trading liabilities & \\
\cline { 1 - 1 } Borrowed money & \\
\cline { 1 - 1 } Soreign exchanges & \\
\cline { 1 - 1 } Othert-term corporate bonds liabilities & \\
\cline { 1 - 1 } Reserve for employees' bonus & \\
\cline { 1 - 1 } Reserve for directors' bonus & \\
\cline { 1 - 1 } Other reserves &
\end{tabular}

Note1: Deposits include Current deposits, Ordinary deposits, Savings deposits, Deposits at notice, Time deposits and Installment savings.

Note2: Trading liabilities include Trading securities sold for short sales, Derivatives of trading securities, Securities related to trading transactions sold for short sales, Derivatives of securities related to trading transactions and Trading-related financial derivatives. 
Appendix Table 2 Major Events

\begin{tabular}{|l|l|}
\hline \multicolumn{2}{|l|}{ Hokkaido Takushoku Bank } \\
\hline April 1, 1997 & Merger with Hokkaido Bank announced \\
\hline September 6, 1997 & Announcement revoked \\
\hline October 1, 1997 & Capital adequacy ratio as of September 1997 lowered \\
\hline November 17, 1997 & Bankrupt. Business transferred to Hokuyo Bank \\
\hline November 18, 1997 & $\begin{array}{l}\text { Transfer to a special section, "the post for stocks under special } \\
\text { supervision" }\end{array}$ \\
\hline May 27, 1998 & $\begin{array}{l}\text { Transfer to a special section, "the temporary post for stocks to be } \\
\text { delisted" }\end{array}$ \\
\hline August 27, 1998 & Removal from the Tokyo Stock Exchange \\
\hline
\end{tabular}

\begin{tabular}{|l|l|}
\hline Long-term Credit Bank of Japan (LTCB) \\
\hline June 26, 1998 & Merger with Sumitomo Trust Bank announced. \\
\hline August 25, 1998 & Results of a self-assessment disclosed. \\
\hline October 8, 1998 & Merger negotiations with Sumitomo Trust Bank put on hold \\
\hline October 23, 1998 & Found to be insolvent and nationalized. \\
\hline October 23, 1998 & $\begin{array}{l}\text { Announcement of removal from Tokyo Stock Exchange on } \\
\text { October 24, 1998 determined }\end{array}$ \\
\hline
\end{tabular}

\begin{tabular}{|l|l|}
\hline \multicolumn{2}{|l|}{ Nippon Credit Bank (NCB) } \\
\hline October 20, 1998 & Double disposal of non-performing claims announced \\
\hline November 24, 1998 & Estimated negative net worth for fiscal year ending March 1999 \\
\hline November 25, 1998 & Bank's NPL ratio increased to 37\% \\
\hline December 1, 1998 & Approach Chuo Trust Bank with a merger talk \\
\hline December 9, 1998 & Merger with Sumitomo Trust bank abandoned \\
\hline December 12,1998 & Temporally nationalization due to Insolvency \\
\hline December 14, 1998 & $\begin{array}{l}\text { Announcement of and immediate removal from Tokyo Stock } \\
\text { Exchange }\end{array}$ \\
\hline
\end{tabular}

\begin{tabular}{|c|c|}
\hline \multicolumn{2}{|l|}{ Hyogo Bank } \\
\hline April 10, 1995 & Current account deficit for fiscal year ending March 1995 \\
\hline May 30, 1995 & $\begin{array}{l}\text { Unrealized capital losses revealed for fiscal year ending March } \\
1995\end{array}$ \\
\hline August 31, 1995 & Ministry of Finance announced failure. Transfer to a special \\
\hline
\end{tabular}




\begin{tabular}{|l|l|}
\hline & section, “the post for stocks under special supervision” \\
\hline January 29, 1996 & $\begin{array}{l}\text { Operations absorbed by Midori Bank, newly set up bank for } \\
\text { Hyogo Bank }\end{array}$ \\
\hline
\end{tabular}

\begin{tabular}{|l|l|}
\hline \multicolumn{2}{|l|}{ Taiheiyo Bank } \\
\hline March 30,1996 & Liquidation of Taiheiyo bank announced \\
\hline March 31, 1996 & $\begin{array}{l}\text { Transfer to a special section, "the post for stocks under special } \\
\text { supervision" }\end{array}$ \\
\hline September 31, 1996 & $\begin{array}{l}\text { Operations absorbed by Wakashio Bank, newly set up bank for } \\
\text { Taiheiyo Bank by Sakura Bank (Mitsui Sumitomo Bank) }\end{array}$ \\
\hline
\end{tabular}

\begin{tabular}{|c|c|}
\hline \multicolumn{2}{|l|}{ Hanwa Bank } \\
\hline April 4, 1996 & $\begin{array}{l}\text { Earning estimate of fiscal year ending March } 1996 \text { lowered, } \\
\text { outstanding amount of non-performing loans announced }\end{array}$ \\
\hline November 6, 1996 & $\begin{array}{l}\text { Earning estimate of fiscal year ending September } 1996 \text { lowered to } \\
\text { overall deficit }\end{array}$ \\
\hline November 21, 1996 & Ordered to suspend business, except for repayment of deposits \\
\hline November 22, 1996 & $\begin{array}{l}\text { Announcement of removal from Osaka Stock Exchange on } \\
\text { February 22, } 1997\end{array}$ \\
\hline
\end{tabular}

\begin{tabular}{|c|c|}
\hline \multicolumn{2}{|c|}{ Tokyo Sowa Bank } \\
\hline May 14, 1999 & Confirmed as undercapitalized bank. \\
\hline May 29, 1999 & Bank's risk adjusted capital fell to $2.42 \%$ \\
\hline June 1, 1999 & Prompt corrective actions taken \\
\hline June 12,1999 & Filed for protection under Deposit Insurance Law \\
\hline June 13, 1999 & $\begin{array}{l}\text { Announcement of removal from Tokyo Stock Exchange on } \\
\text { September 13, } 1999\end{array}$ \\
\hline
\end{tabular}

\begin{tabular}{|l|l|}
\hline Ashikaga Bank & $\begin{array}{l}\text { Estimated negative net worth for fiscal year ending March } 2003 . \\
\text { The Bank's risk adjusted capital fell lower than 5\% }\end{array}$ \\
\hline Mpril 29, 2003 & $\begin{array}{l}\text { Negative net worth for fiscal year ending March 2003 reported. } \\
\text { The bank's risk adjusted capital fell lower than 4.6\% }\end{array}$ \\
\hline November 14, 2003 & Public capital injection planned \\
\hline November 29, 2003 & Found to be insolvent and nationalized \\
\hline
\end{tabular}


Appendix Table 3 Data Summary

\begin{tabular}{|c|c|c|c|}
\hline $\begin{array}{l}\text { Name of } \\
\text { bank }\end{array}$ & DD period & Stock price & Financial statement \\
\hline $\begin{array}{l}\text { Hokkaido } \\
\text { Takushoku } \\
\text { Bank }\end{array}$ & $\begin{array}{l}\text { March 31, } 1986 \text { to } \\
\text { August 26, } 1998\end{array}$ & $\begin{array}{l}\text { April 1, } 1985 \text { to August } \\
26,1998\end{array}$ & March 1985 to March 1998 \\
\hline LTCB & $\begin{array}{l}\text { March 31, } 1986 \text { to } \\
\text { October 23, } 1998\end{array}$ & $\begin{array}{l}\text { April } 1,1985 \text { to October } \\
23,1998\end{array}$ & $\begin{array}{l}\text { March } 1985 \text { to March } \\
\text { 1998* }\end{array}$ \\
\hline NCB & $\begin{array}{l}\text { March 31, } 1986 \text { to } \\
\text { December 11, } 1998\end{array}$ & $\begin{array}{l}\text { April 1, } 1985 \text { to } \\
\text { December 11, } 1998\end{array}$ & $\begin{array}{l}\text { March } 1985 \text { to March } \\
\text { 1998* }\end{array}$ \\
\hline $\begin{array}{l}\text { Hyogo } \\
\text { Bank }\end{array}$ & $\begin{array}{l}\text { March 31, } 1986 \text { to } \\
\text { January 26, } 1996\end{array}$ & $\begin{array}{l}\text { April 1, } 1985 \text { to January } \\
26,1996\end{array}$ & March 1985 to March 1996 \\
\hline $\begin{array}{l}\text { Taiheiyo } \\
\text { Bank }\end{array}$ & $\begin{array}{l}\text { March 31, } 1986 \text { to } \\
\text { September } 13,1996\end{array}$ & $\begin{array}{l}\text { April 1, } 1985 \text { to } \\
\text { September } 13,1996\end{array}$ & March 1985 to March 1996 \\
\hline $\begin{array}{l}\text { Hanwa } \\
\text { Bank }\end{array}$ & $\begin{array}{l}\text { November } 30,1990 \text { to } \\
\text { February } 21,1997\end{array}$ & $\begin{array}{l}\text { December 1, } 1989 \text { to } \\
\text { February 21, } 1997\end{array}$ & March 1985 to March 1997 \\
\hline $\begin{array}{l}\text { Tokyo } \\
\text { Sowa Bank }\end{array}$ & $\begin{array}{l}\text { March 31, } 1986 \text { to } \\
\text { September 10, } 1999\end{array}$ & $\begin{array}{l}\text { April 1, } 1985 \text { to } \\
\text { September 10, } 1999\end{array}$ & March 1985 to March 1999 \\
\hline $\begin{array}{l}\text { Ashikaga } \\
\text { Bank }\end{array}$ & $\begin{array}{l}\text { March 31, } 1986 \text { to } \\
\text { January 23, } 2004\end{array}$ & $\begin{array}{l}\text { April } 1,1985 \text { to January } \\
23,2004^{* *}\end{array}$ & $\begin{array}{l}\text { March } 1985 \text { to March } \\
2003^{* * *}\end{array}$ \\
\hline
\end{tabular}

*The data in March 1998 is used for March 1999.

**April 1, 1985 to March 4, 2003 (Ashikaga Bank) and March 11, 2003 to January 23, 2004 (Ashigin FG).

***The consolidated data of Ashigin FG in March 2003 is used for March 2004. 